Key Words: F Area, seepage basins, groundwater, humate injection, enhanced attenuation

Retention: Permanent

\title{
PRELIMINARY DATA REPORT: \\ HUMATE INJECTION AS AN ENHANCED ATTENUATION METHOD AT THE F-AREA SEEPAGE BASINS, SAVANNAH RIVER SITE (U)
}

\author{
M. R. Millings \\ M. B. Amidon \\ M. E. Denham \\ B. B. Looney
}

\section{SEPTEMBER 2013}

Savannah River National Laboratory

Savannah River Nuclear Solutions

Aiken, SC 29808

Prepared for the U.S. Department of Energy Under 


\section{DISCLAIMER}

This work was prepared under an agreement with and funded by the U.S. Government. Neither the U. S. Government or its employees, nor any of its contractors, subcontractors or their employees, makes any express or implied:

1. warranty or assumes any legal liability for the accuracy, completeness, or for the use or results of such use of any information, product, or process disclosed; or

2. representation that such use or results of such use would not infringe privately owned rights; or

3. endorsement or recommendation of any specifically identified commercial product, process, or service.

Any views and opinions of authors expressed in this work do not necessarily state or reflect those of the United States Government, or its contractors, or subcontractors.

Printed in the United States of America

Prepared for

U.S. Department of Energy 


\section{REVIEWS AND APPROVALS}

\section{AUTHORS:}

M. R. Millings, SRNL-Environmental Restoration Technologies

Date

M. B. Amidon, SRNL-Environmental Restoration Technologies

Date

M. E. Denham, SRNL-Environmental Restoration Technologies

Date

B. B. Looney, SRNL-Environmental Restoration Technologies

Date

\section{APPROVALS:}

T. O. Oliver, Manager, SRNL- Environmental Restoration Technologies

Date

R. S. Aylward, Manager, SRNL- Environmental Restoration Technologies

Date 


\section{TABLE OF CONTENTS}

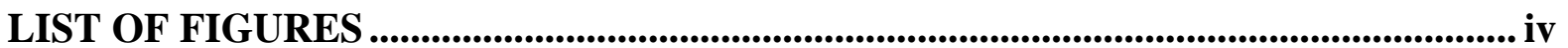

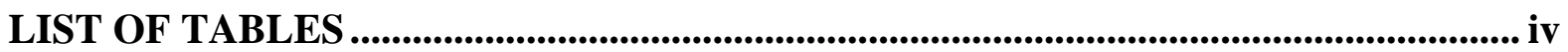

LIST OF ACRONYMS AND ABBREVIATIONS .................................................................. V

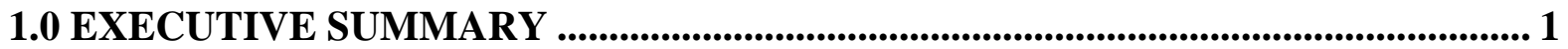

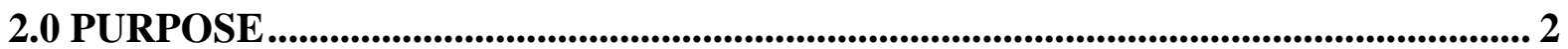

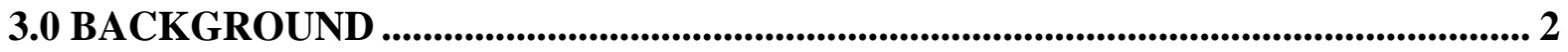

3.1 Site Description ................................................................................................................... 3

3.2 Operational History........................................................................................................... 4

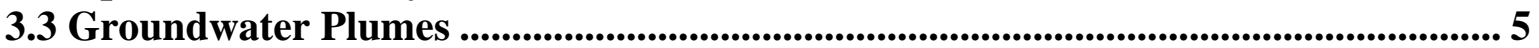

3.4 Groundwater Actions ........................................................................................... 5

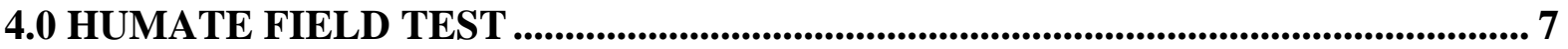

4.1 Humate Amendment ........................................................................................................... 7

4.2 Identification of Wells ............................................................................................................ 10

4.3 FOB 16D Profiling ....................................................................................................... 14

4.4 Injection................................................................................................................................. 16

4.5 Sampling and Analysis ..................................................................................................... 17

4.5.1 Laboratory Analyses ................................................................................................... 18

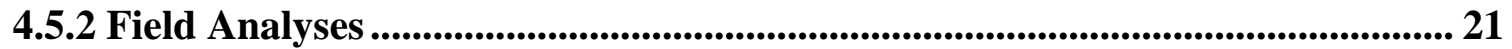

5.0 PRELIMINARY FIELD RESULTS ............................................................................. 22

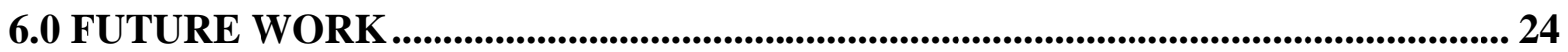

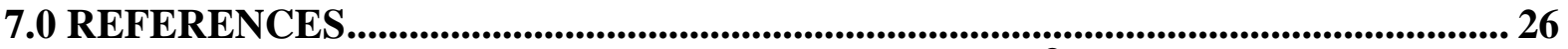

APPENDIX A. Median Metal Concentrations in Huma $K^{\odot}$............................................... 29

APPENDIX B. Pictures of Humate Injection................................................................. 30 


\section{LIST OF FIGURES}

Figure 1. Location of the F-Area Seepage Basins …………................................................... 4

Figure 2. Planar View of the Conceptual Behavior of Humate During Injection into the Well at the Center of the Injectate Volume

Figure 3. Monitoring Well and Injection Well Locations, Upper Aquifer Zone Potentiometric

Surface, and General Groundwater Flow Direction........................................................ 12

Figure 4. Cross-Section Showing Monitoring Well and Injection Well Screen Zones ........... 13

Figure 5. Field Parameter Depth Profile in FOB 16D ………………….............................. 15

Figure 6. Schematic of Injection Setup............................................................................... 17

Figure 7. Picture of Acid Preserved Sample Bottles with Separation of Humate Fraction and

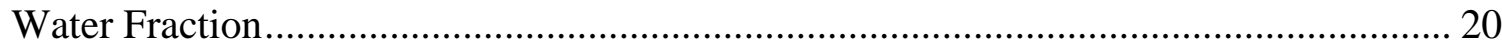

Figure 8. Spectrometer Calibration for Huma $\mathrm{K}^{\odot}$ Solution $(\mathrm{mg} / \mathrm{L})$...................................... 22

Figure 9. Huma $\mathrm{K}^{\odot}$ Concentrations in the Injectate Solution and FOB 16D .......................... 23

Figure 10. pH in FOB 16D: Baseline Monitoring versus Post-Injection Monitoring ............ 23

Figure 11. Continuous Monitoring YSI Data from FOB 16D ................................................ 25

\section{LIST OF TABLES}

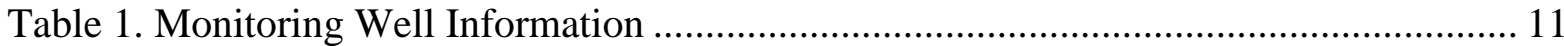

Table 2. pH and Radionuclide Concentrations in Monitoring and Injection Wells................. 13

Table 3. Field Parameters from FOB 16D Purge Test.............................................................. 14

Table 4. Sample and Analysis Information for the Humate Injection Sample Events ............ 18 


\section{LIST OF ACRONYMS AND ABBREVIATIONS}

\begin{tabular}{ll} 
\% & percent \\
ABRS & Attenuation-Based Remedies for the Subsurface \\
AFRI & Applied Field Research Initiative \\
C & Celsius \\
cm & centimeter \\
Cs-137 & cesium-137 \\
DO & dissolved oxygen \\
DOC & dissolved organic carbon \\
DOE & Department of Energy \\
FASB & F-Area Seepage Basins \\
ft & feet \\
I-129 & iodine-129 \\
kg & kilograms \\
km & kilometer \\
L & liters \\
m & meter \\
MDS & multiparameter display system \\
mg & milligram \\
mi & mile \\
mV & millivolts \\
ntu & nephelometric turbidity unit \\
OMRI & organic materials review institute \\
ORP & oxidation reduction potential \\
RCRA & Resource Conservation and Recovery Act \\
s & second \\
Sr-90 & strontium-90 \\
SRNL & Savannah River National Laboratory \\
SRNS & Savannah River Nuclear Solutions \\
SRS & Savannah River Site \\
Tc-99 & technetium-99 \\
U-234 & uranium-234 \\
U-235 & uranium-235 \\
U-238 & uranium-238 \\
UAZ & Upper Aquifer Zone \\
uS & microsiemens \\
WSRC & Westinghouse Savannah River Company, LLC (before Dec. 8, 2005) \\
& Washington Savannah River Company, LLC (after Dec. 8, 2005) \\
& \\
\hline &
\end{tabular}




\subsection{EXECUTIVE SUMMARY}

A field test of a humate technology for uranium and I-129 remediation was conducted at the F-Area Field Research Site as part of the Attenuation-Based Remedies for the Subsurface Applied Field Research Initiative (ABRS AFRI) funded by the DOE Office of Soil and Groundwater Remediation. Previous studies have shown that humic acid sorbed to sediments strongly binds uranium at mildly acidic $\mathrm{pH}$ and potentially binds iodine-129 (I-129). Use of humate could be applicable for contaminant stabilization at a wide variety of DOE sites however pilot field-scale tests and optimization of this technology are required to move this technical approach from basic science to actual field deployment and regulatory acceptance.

The groundwater plume at the F-Area Field Research Site contains a large number of contaminants, the most important from a risk perspective being strontium-90 (Sr-90), uranium isotopes, I-129, tritium, and nitrate. Groundwater remains acidic, with $\mathrm{pH}$ as low as 3.2 near the basins and increasing to the background $\mathrm{pH}$ of approximately 5at the plume fringes. The field test was conducted in monitoring well FOB 16D, which historically has shown low pH and elevated concentrations of Sr-90, uranium, I-129 and tritium. The field test included three months of baseline monitoring followed by injection of a potassium humate solution and approximately four and half months of post monitoring. Samples were collected and analyzed for numerous constituents but the focus was on attenuation of uranium, Sr-90, and I-129.

This report provides background information, methodology, and preliminary field results for a humate field test. Results from the field monitoring show that most of the excess humate (i.e., humate that did not sorb to the sediments) has flushed through the surrounding formation. Furthermore, the data indicate that the test was successful in loading a band of sediment surrounding the injection point to a point where $\mathrm{pH}$ could return to near normal during the study timeframe. Future work will involve a final report, which will include data trends, correlations and interpretations of laboratory data. 


\subsection{PURPOSE}

The purpose of this study was to field test a humate technology for uranium and I-129 remediation at the F-Area Field Research Site. This work addresses one of the subtasks under Task 1 Enhanced Attenuation of Uranium and I-129 by Humic Acid in the ABRS AFRI Task Technical Plan. Uranium and I-129 are primary contaminants of concern at the F-Area Applied Field Research Site. Both are also of concern at Hanford and uranium is a concern across the Department of Energy (DOE) complex. Bench-scale studies conducted at Lawrence Berkeley National Laboratory showed that sorbed humic acid strongly binds uranium at mildly acidic pH and potentially binds I-129 (Wan et al., 2011). This work suggests humate would be a versatile enhanced attenuation amendment to use for hot-spot treatment at the F-Area Applied Field Research site where both contaminants are present in acidic groundwater. Use of humate could also be applicable for contaminant stabilization at a wide variety of other DOE sites. Pilot field-scale tests and optimization of this technology are required to move this technical approach from basic science to actual field deployment and regulatory acceptance. This document provides the background information, methodology, and preliminary field results for a humate field test at the F-Area Field Research Site.

\subsection{BACKGROUND}

The F-Area Hazardous Waste Management Facility consists of three unlined, earthen surface impoundments referred to as seepage basins. From 1955 through 1988, the F-Area seepage basins (FASB) received approximately 1.8 billion gallons (7.1 billion liters) of low-level waste solutions originating from the processing of uranium slugs and irradiated fuel in the FArea Separations Facility. The effluents were acidic (wastewater with nitric acid) and low activity waste solutions containing a wide variety of radionuclides and dissolved metals (Killian et al., 1987; Cummins et al., 1991). Waste solutions were transported approximately 3,000 feet from each processing area through underground vitrified clay pipes to the basins. After entering the basin, the wastewater was allowed to evaporate and to seep into the underlying soil. The purpose of the basins was to take advantage of the interaction with the basin soils to minimize the migration of contaminants to exposure points. Though the 
seepage basins essentially functioned as designed, the acidic nature of the basin influent caused mobilization of some metals and radionuclides resulting in groundwater contaminant plumes.

Historically, some 70 environmental investigations have been conducted in the vicinity of the basins since the 1960's (WSRC, 2000a). Monitoring of the groundwater at the basins began in the late-1950s and has continued since that time. Over the years, various types and numbers of wells, seepline monitoring points, and surface water locations have been utilized for assessing impacts and remedial efforts associated with the FASB. Numerous studies and reports are available documenting the studies (e.g., Reichert and Fenimore, 1962; Fenimore and Horton, 1972; Horton and Carothers, 1974; Kantelo, 1987; Killian et al., 1987; Looney et al., 1988; Haselow et al., 1990; Dixon et al., 1997; Dixon and Rogers, 1994; Dixon, 1996; Koch and Dixon, 1998; Friday, 2001; Friday, 2007; SRNS, 2012; Amidon and Millings, 2013; Millings and Amidon, 2013).

\subsection{SITE DESCRIPTION}

The FASB are located in the central portion of the Savannah River Site (SRS), between Upper Three Runs Creek and Fourmile Branch (Figure 1). These surface water bodies drain the shallow groundwater system in the area. There is a gentle slope from the basins to Fourmile Branch with an average gradient of $92.6 \mathrm{ft} / \mathrm{mi}$ (45.5 m/km) (Killian et al., 1987).

The FASB cover approximately 6.5 acres and surface elevation range from approximately 55 to $90 \mathrm{~m}$ (180 to $295 \mathrm{ft}$ ) above mean sea level. Ground cover at the FASB consists predominantly of grasses, planted forest, and gravel roads. 


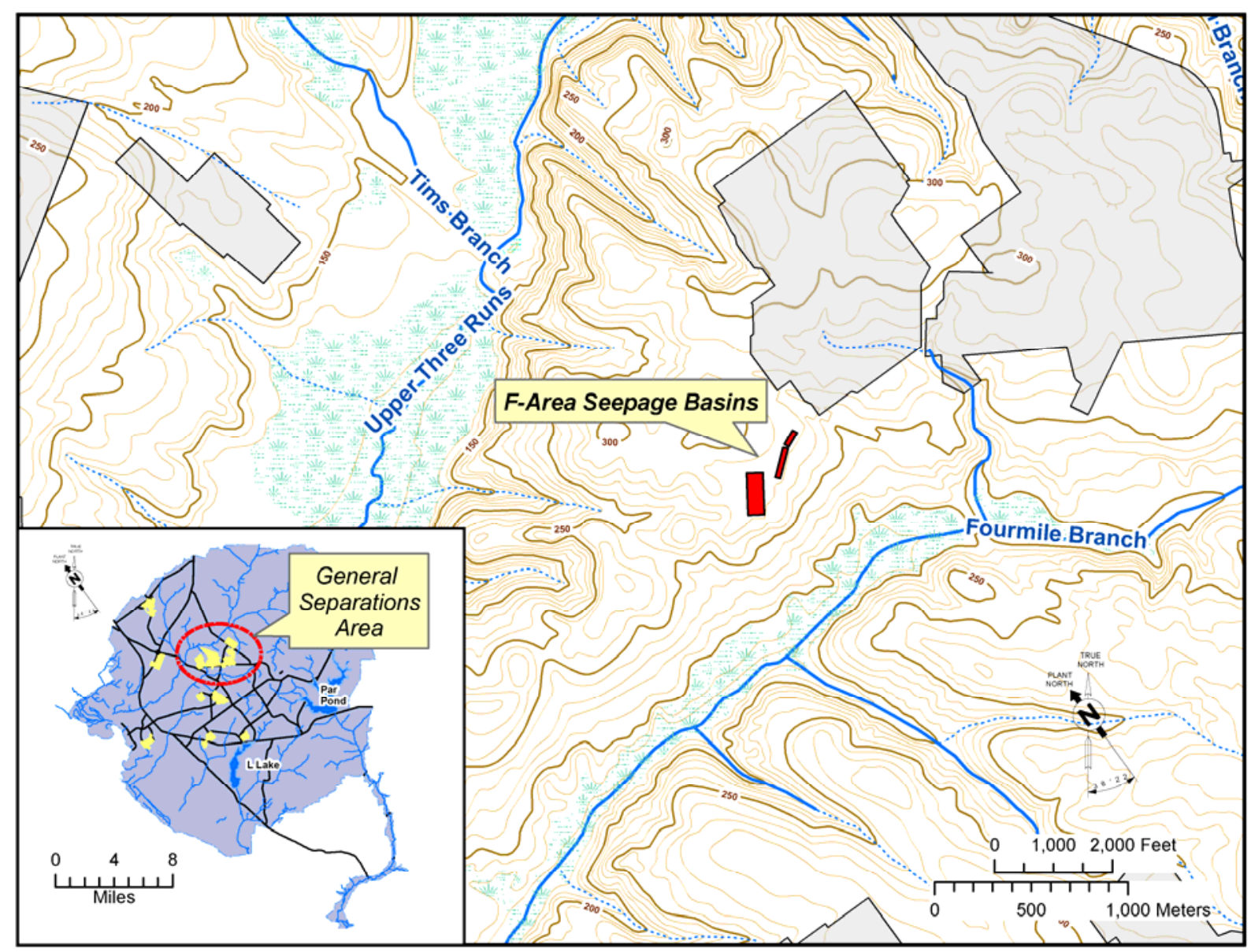

Figure 1. Location of the F-Area Seepage Basins

\subsection{OPERATIONAL HISTORY}

The FASB began operating in 1955 and received processed liquid effluent from the Separations Facilities until 1988. In 1986, the determination was made that the basins should be regulated under the Resource Conservation and Recovery Act (RCRA) as hazardous waste disposal facilities, and closure plans were initiated. The basins were closed by dewatering, physically and chemically stabilizing the remaining sludge, and covering them with a protective multilayer system to reduce rainwater infiltration. The basin closures were completed in 1991. 


\subsection{GROUNDWATER PLUMES}

When the FASB were constructed, the belief was that most of the radionuclides would be bound in the soils beneath the basins and would not significantly pollute groundwater. This was true for many radionuclides disposed including plutonium isotopes and cesium-137 (Cs137), but many such as Sr-90, uranium isotopes, I-129, technetium-99 (Tc-99), and tritium migrated to the groundwater.

The geology of the site is made up of heterogeneous poorly consolidated quartz sands and clays. The quartz sands contain varying amounts of surface active minerals consisting mostly of kaolinite and goethite. Other minor clay minerals are present as well. The plume is stratified within the water table aquifer moving mostly within the highly transmissive Irwinton Sand along the top of a local confining unit commonly referred to as the Tan Clay, which confines the aquifer below. The plume crops out at seeplines along a stream approximately 400-600 meters from the basins.

The plume contains a large number of contaminants, the most important from a risk perspective being Sr-90, uranium isotopes, I-129, tritium, and nitrate. Groundwater remains acidic, with $\mathrm{pH}$ as low as 3.2 near the basins and increasing to a $\mathrm{pH}$ of approximately 5 downgradient. The Atlantic Coastal Plain aquifer sediments that underlie the F Area have been bathed with acidic solutions for about 40 years, and changes to their mineralogy and texture from the acidic groundwater are currently under study.

\subsection{GROUNDWATER ACTIONS}

In 1997, SRS designed and installed a pump-treat-and-re-inject system with a water treatment unit designed to trap the untreatable tritium in a continuous loop by extracting groundwater from downgradient, removing contaminants other than tritium from the water, and re-injecting the treated water upgradient of the seepage basins. The treatment system consisted of precipitation/flocculation, reverse osmosis, and ion exchange. The pump-andtreat system operated as designed, but had two significant drawbacks. It was very expensive 
to operate and generated large amounts of radioactive solid waste. Hence, SRS sought another more efficient way to treat the groundwater contaminant plume. Operation of the water treatment unit began in 1999 (WSRC, 2000b) and were suspended in 2003 (WSRC, 2005).

In 2004, the pump-and-treat system was replaced by a hybrid funnel-and-gate system that was installed about 300 meters from the stream (WSRC, 2005; SRNS, 2012). The purpose of the funnel-and-gate is to slow migration of contaminated groundwater and to funnel it through in situ treatment zones at the gates. Extensive geologic characterization showed that much of the plume migrated along "troughs" at the top of the clay layer that confines the lower aquifer. The walls (or engineered subsurface barriers) were installed across these features to slow contaminant migration and force it through the gates. The treatment zones at the gates attenuate migration of uranium, Sr-90, and I-129 by sorption or precipitation. Tritium migration is slowed by the walls and additional decrease in tritium concentrations is achieved when the stratified plume mixes with less contaminated groundwater as it migrates up through the gates.

The walls average 0.9 meters in thickness and have an average permeability on the order of $1 \times 10^{-7} \mathrm{~cm} / \mathrm{s}$. The walls are installed to a depth of about 20 meters and key into the Tan Clay at the bottom of the aquifer. Approximately 730 linear meters of barrier wall were installed in four segments, forming three gates.

Treatment zones for uranium and Sr-90 at the gates are maintained by neutralizing acidity of the groundwater and mineral surfaces with injections of an alkaline solution. This causes sorption of the contaminants and possible precipitation of uranium phases. Periodic injections are performed with the frequency at each gate dictated by sentry monitoring wells located downgradient.

Monitoring of the performance of the funnel-and-gate with base injection over the past seven years indicates that it is functioning as planned. Analysis of subsurface cores collected downgradient of the middle gate shows that an elevated $\mathrm{pH}$ treatment zone has been 
established. Monitoring of groundwater indicates that tritium flux has been reduced to target levels and regulatory limits on concentrations of Sr-90 and uranium have been achieved downgradient of the treatment system.

In 2009, a pilot study was initiated to evaluate the removal of I-129 by the injection of particles of solid silver chloride (SRNS, 2012). Contaminant I-129 and natural I-127 react with the silver chloride to form insoluble silver iodide, removing I-129 from the groundwater. In 2011, a modification to the RCRA permit was approved to deploy silver chloride technology at the middle gate as part of the corrective action. The treatment zone was from the top of the water table down to the tan clay confining zone ( 25 to 50 feet below ground surface). Injection was performed starting at the bottom of the aquifer and proceeded upward pumping a specific volume of amendment into each zone at 2.5 foot intervals. Evaluation of the performance of the silver chloride treatment zones continues.

\subsection{HUMATE FIELD TEST}

Preparations for the humate field test included development of a Sampling and Analysis Plan (Amidon et al., 2012); completion of the Underground Injection Control Permit Application (SRNS, 2013) with approval by South Carolina Department of Health and Environmental Control; and completion of the facilities owner's hazard review (Area Completion Projects Assisted Hazards Analysis Work Package).

\subsection{HUMATE AMENDMENT}

As an applied research test, it was important to choose a relatively inexpensive and commercially available product to demonstrate whether the humate technology could be a realistic remedial option for large groundwater plumes typical of DOE sites. For this field study, Huma $\mathrm{K}^{\odot}$ was chosen as the humate amendment because of its ease of use with the dry flake as well as existing data and experience with the amendment (Millings et al., 2008; Millings et al., 2013). 
Huma $\mathrm{K}^{\odot}$ is a commercially available, dry flake, organic amendment manufactured by Land and Sea Organics. The amendment is high in humic and fulvic compounds and is just one of several brands produced for large scale use as soil conditioners to boost productivity in organic agriculture. It is certified by the organic materials review institute (OMRI) for use in organic farming based on a number of stringent criteria including low concentrations of trace metals (Appendix A).

Huma $\mathrm{K}^{\odot}$ is made from leonardite, an organic rich mineral, by extracting the raw material with a potassium hydroxide base solution and then drying it. The high $\mathrm{pH}$ solublizes the humic acid molecules and generates a dark-brown highly-concentrated solution, rich in humic acid, which can be diluted for use. Importantly, while such solutions are commonly called soluble humic acid, they are actually basic with $\mathrm{pH}$ greater than 7. Land and Sea Organics offers a soluble humic acid $12 \%$ solution known as TriHumic ${ }^{\odot}$ or the dry flake material, Huma $\mathrm{K}^{\odot}$.

A simple conceptual model of humate injection into a single well was developed based on the groundwater conditions and $\mathrm{pH}$ dependent behavior of humate. At the $\mathrm{pH}$ of the injection solution, about 9, humate is highly soluble and does not sorb effectively to aquifer minerals. At low $\mathrm{pH}$ humate sorbs effectively and can exsolve into a separate phase if concentrations are high enough and $\mathrm{pH}$ low enough. Humate also imparts a high alkalinity to the solution relative to other common anions.

When humate solution is injected into the acidic groundwater the initial mixing and contact with acidified aquifer mineral surfaces lowers the $\mathrm{pH}$ of the humate solution causing humate to sorb in a band around the injection well. As additional humate solution is injected, the alkalinity overcomes the mineral acidity causing humate to desorb and move outward from the well. The humate sorption band expands around the injection well until injection is complete. At this point the conditions would resemble those in Figure 2. Minimal humate will be sorbed near the injection well; most will be sorbed near the outer edge of the injected solution volume. 


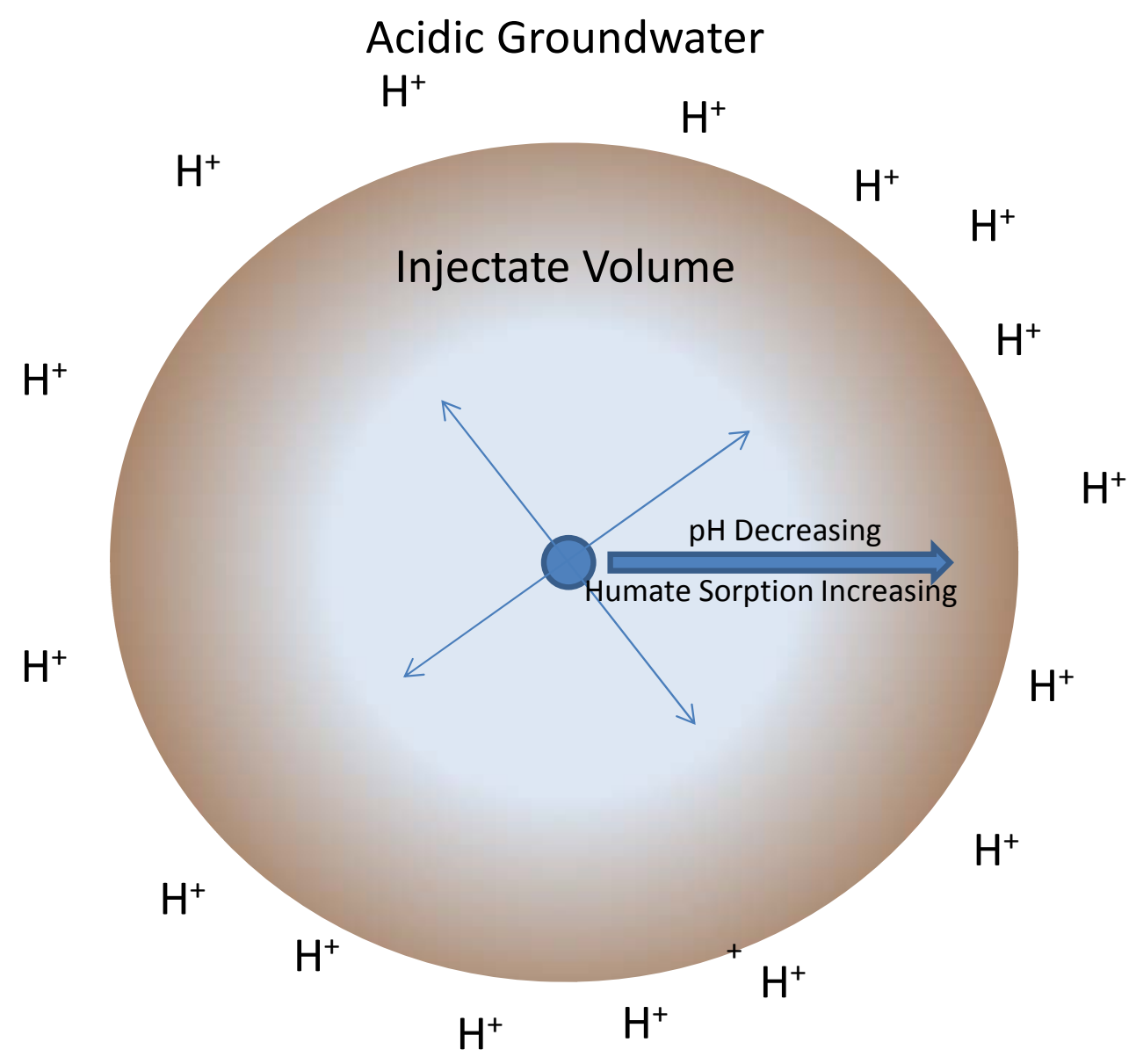

Figure 2. Planar View of the Conceptual Behavior of Humate During Injection into the Well at the Center of the Injectate Volume

Upon completion of injection, groundwater begins flowing back across the injection zone. The acidity of the groundwater entering the injection zone is neutralized by the alkalinity on mineral surfaces, causing retardation of the high to low $\mathrm{pH}$ gradient as it moves toward the injection well. It is hypothesized that Sr-90 and uranium will be sorbed to humate in the humate band, and initially, will also be sorbed closer to the injection well because of the elevated pH. I-129 will behave differently. It will be desorbed from aquifer minerals by the advancing elevated $\mathrm{pH}$ during injection and will concentrate in the humate band because of the lower $\mathrm{pH}$ and interaction with the humate. 
The goal of this field test is to allow the post-injection $\mathrm{pH}$ to return to near baseline values at the injection-extraction well while observing the concentrations of Sr-90, uranium, and I-129. If concentrations of these remain below baseline after $\mathrm{pH}$ values return to baseline, then it can be assumed that sorbed humate is attenuating these contaminants.

Model runs were performed using groundwater chemistry data, well construction information and a simple Langmuir isotherm to determine the concentration of Huma $\mathrm{K}^{\odot}$ needed in the injectate. The goal was to load a "band" of sediment surrounding the injection point but not overload the sediment to a point where $\mathrm{pH}$ conditions could not return to normal during the study timeframe. Modeling results indicated that approximately 16 to $22 \mathrm{~kg}$ of Huma $\mathrm{K}^{\odot}$ would be needed to generate a $2000 \mathrm{~L}$ injectate solution.

\subsection{IDENTIFICATION OF WELLS}

Historical groundwater data were reviewed along with current well locations to identify a suitable injection well (Amidon et al., 2012). The primary selection criteria included the following:

- An existing shallow well installed in the transmissive zone of the Upper Aquifer Zone within the groundwater plume;

- Not part of any compliance monitoring program;

- Constructed with a 10 or 20 foot screen;

- Exhibits elevated levels of uranium radioisotopes; and

- Not influenced by recent or current groundwater actions.

Other secondary criteria considered but not necessarily viewed as important as previous criteria included the following:

- Located near downgradient well(s); and

- Located near an upgradient well. 
Review of the data identified FOB 16D as the most suitable for injection. Two wells upgradient wells (FSB 94DR and 95DR) and one downgradient well (FSB 126D) were also chosen for monitoring. Table 1 provides construction information for the wells.

Table 1. Monitoring Well Information

\begin{tabular}{|c|c|c|c|c|c|c|c|c|c|}
\hline $\begin{array}{l}\text { Well } \\
\text { ID }\end{array}$ & $\begin{array}{l}\text { Top of } \\
\text { Screen } \\
\text { (ft msl) }\end{array}$ & $\begin{array}{l}\text { Screen } \\
\text { Length } \\
\text { (ft) }\end{array}$ & $\begin{array}{c}\text { Ground } \\
\text { Elevation } \\
\text { (ft msl) }\end{array}$ & $\begin{array}{c}\text { Reference } \\
\text { Elevation } \\
\text { (ft msl) }\end{array}$ & $\begin{array}{c}\text { Total } \\
\text { Depth } \\
\text { (ft) }\end{array}$ & $\begin{array}{c}\text { Well } \\
\text { Diameter } \\
\text { (inches) }\end{array}$ & $\begin{array}{c}\text { Well } \\
\text { Material }\end{array}$ & Pump Type & $\begin{array}{c}\text { Install } \\
\text { Date }\end{array}$ \\
\hline $\begin{array}{l}\text { FOB } \\
16 \mathrm{D}\end{array}$ & 183.7 & 20 & 251.7 & 254.5 & 90.6 & 2 & PVC & $\begin{array}{l}\text { VARIABLE } \\
\text { SPEED } \\
\text { PUMP }\end{array}$ & $\begin{array}{c}\text { Jan } \\
2004\end{array}$ \\
\hline $\begin{array}{l}\text { FSB } \\
\text { 94DR }\end{array}$ & 203.4 & 20 & 278.4 & 281.3 & 97.2 & 4 & PVC & $\begin{array}{l}\text { SINGLE } \\
\text { SPEED } \\
\text { PUMP }\end{array}$ & $\begin{array}{c}\text { Oct } \\
1990\end{array}$ \\
\hline $\begin{array}{l}\text { FSB } \\
\text { 95DR }\end{array}$ & 207.0 & 20 & 282.0 & 284.4 & 97.1 & 4 & PVC & $\begin{array}{l}\text { SINGLE } \\
\text { SPEED } \\
\text { PUMP }\end{array}$ & $\begin{array}{l}\text { Sept } \\
1990\end{array}$ \\
\hline $\begin{array}{l}\text { FSB } \\
126 D\end{array}$ & 183.1 & 10 & 236.9 & 239.8 & 66.4 & 2 & PVC & $\begin{array}{l}\text { VARIABLE } \\
\text { SPEED } \\
\text { PUMP }\end{array}$ & $\begin{array}{c}\text { Dec } \\
2003\end{array}$ \\
\hline
\end{tabular}

Figure 3 shows the location of the monitoring wells. The wells are all located along the primary flow path downgradient from the seepage basins but upgradient of the subsurface engineered barriers (walls) and the base injection system. Although a more ideal study plan would have encompassed upgradient and downgradient wells that were closer in distance to the injection well, funding constraints required the use of existing monitoring wells. Both the upgradient wells (FSB 94DR and 95DR) and downgradient well (FSB 126D) are positioned approximately $400 \mathrm{ft}$ from the injection well (FOB 16D). 


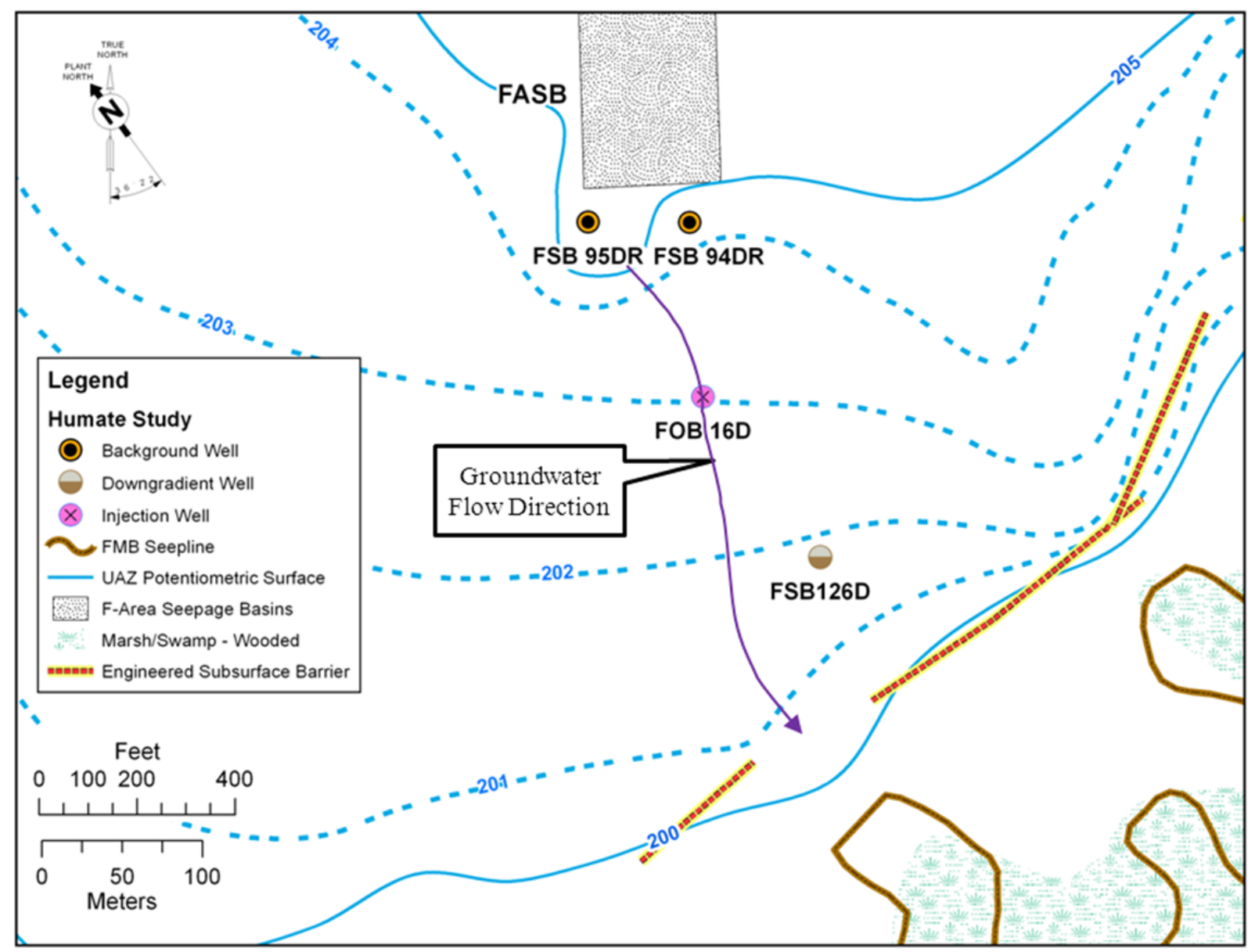

Figure 3. Monitoring Well and Injection Well Locations, Upper Aquifer Zone Potentiometric Surface, and General Groundwater Flow Direction

All of the screen zones for the wells are located within the highly transmissive zone of the Upper Aquifer Zone above the Tan Clay (Figure 4). The upgradient wells (FSB 94DR and 95DR) have $20 \mathrm{ft}$ screens that straddle or are near the water table. The injection well, FOB $16 \mathrm{D}$, also has a $20 \mathrm{ft}$ screen but the screen zone is deeper and terminates in the Tan Clay. The downgradient well, FSB 126D, has a $10 \mathrm{ft}$ screen, which is located immediately above the Tan Clay.

Table 2 provides median values for constituents of interest for the wells chosen for the study. Values reflect available data from 2004 through 2012. Note that the results for FOB 16D reflect only a few sample events and not a long monitoring history. 


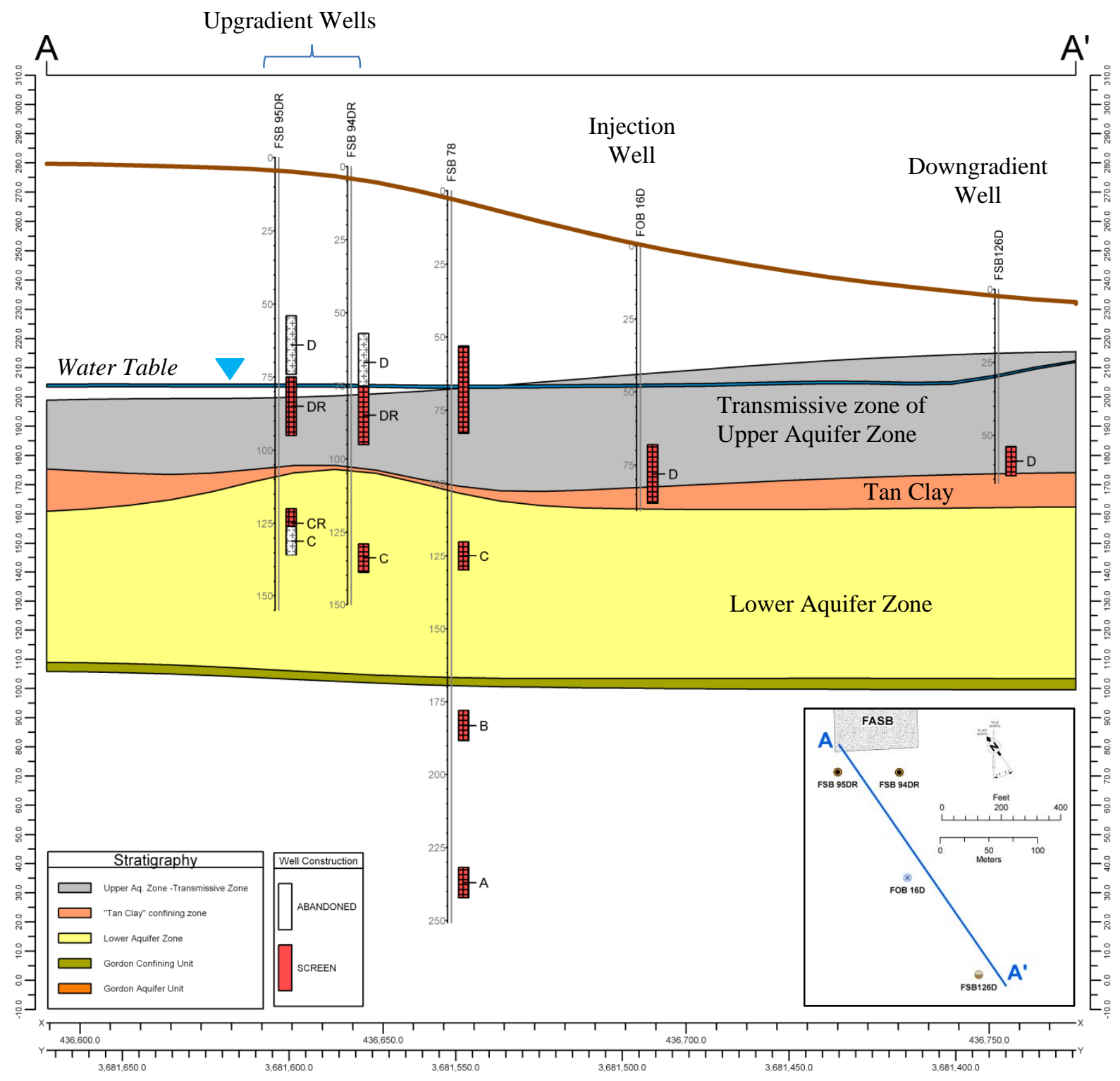

Figure 4. Cross-Section Showing Monitoring Well and Injection Well Screen Zones

Table 2. pH and Radionuclide Concentrations in Monitoring and Injection Wells

\begin{tabular}{|c|c|c|c|c|}
\hline & FSB 94DR & FSB 95DR & FOB 16D & FSB 126D \\
\hline $\mathbf{p H}$ & 3.7 & 3.5 & 3.3 & 3.6 \\
\hline $\mathbf{I - 1 2 9}(\mathbf{p C i} / \mathbf{L})$ & 123 & 721 & 121 & 70 \\
\hline Sr-90 (pCi/L) & 35 & 129 & 231 & 226 \\
\hline Tritium (pCi/mL) & 1300 & 941 & 2589 & 2440 \\
\hline $\mathbf{U}$ (ug/L) & 561 & 1029 & 701 & 3173 \\
\hline
\end{tabular}




\subsection{FOB 16D PROFILING}

Prior to the humate injection, a purge test was conducted on FOB $16 \mathrm{D}$ to verify the quality of the well. It was purged for approximately 4 hours at a maximum of 4.8 gallons per minute (gpm) and yielded approximately 800 gallons. Field parameters were monitored during the test. Table 3 provides the field parameters at the end of the test. These data are similar to other data collected from surrounding wells within the same hydrologic horizon.

Table 3. Field Parameters from FOB 16D Purge Test

\begin{tabular}{|c|c|c|c|c|c|c|c|}
\hline Date & $\mathbf{p H}$ & $\begin{array}{c}\text { Specific } \\
\text { Conductivity } \\
(\mathbf{u S} / \mathbf{c m})\end{array}$ & $\begin{array}{c}\text { DO } \\
\mathbf{( \% )}\end{array}$ & $\begin{array}{c}\text { DO } \\
\mathbf{( m g / L )}\end{array}$ & $\begin{array}{c}\text { Temperature } \\
(\mathbf{C})\end{array}$ & $\begin{array}{c}\text { ORP } \\
(\mathbf{m V})\end{array}$ & $\begin{array}{c}\text { Turbidity } \\
\text { (ntu) }\end{array}$ \\
\hline $2 / 14 / 2013$ & 3.29 & 940 & 6.7 & 0.63 & 19.73 & 507 & 4.8 \\
\hline
\end{tabular}

After having the dedicated pump removed from the well, a depth profile was conducted to assess field parameters in the screen zone and to determine if stratification was occurring in within the well screen that may indicate the need to target a specific depth for the injection of the Huma $\mathrm{K}^{\odot}$ (Figure 5). Results were consistent with a previous depth profile conducted in 2011 and indicated that no major changes had occurred in the well screen. The lower screen zone exhibited low pH ( 3.5), elevated specific conductivity (800 uS/cm), low DO ( $<0.5$ $\mathrm{mg} / \mathrm{L})$, and relatively elevated ORP (300 mV).

For the humate injection test, the lower screen was targeted for placement of a YSI sonde, a bladder pump, and the injected humate. The YSI sonde, which included a datalogger, monitored field parameters in the well during the entire humate field test (March 19 through September 9, 2013). A QED bladder pump (model T1200M) was installed and used to sample FOB 16D during the humate field test. 


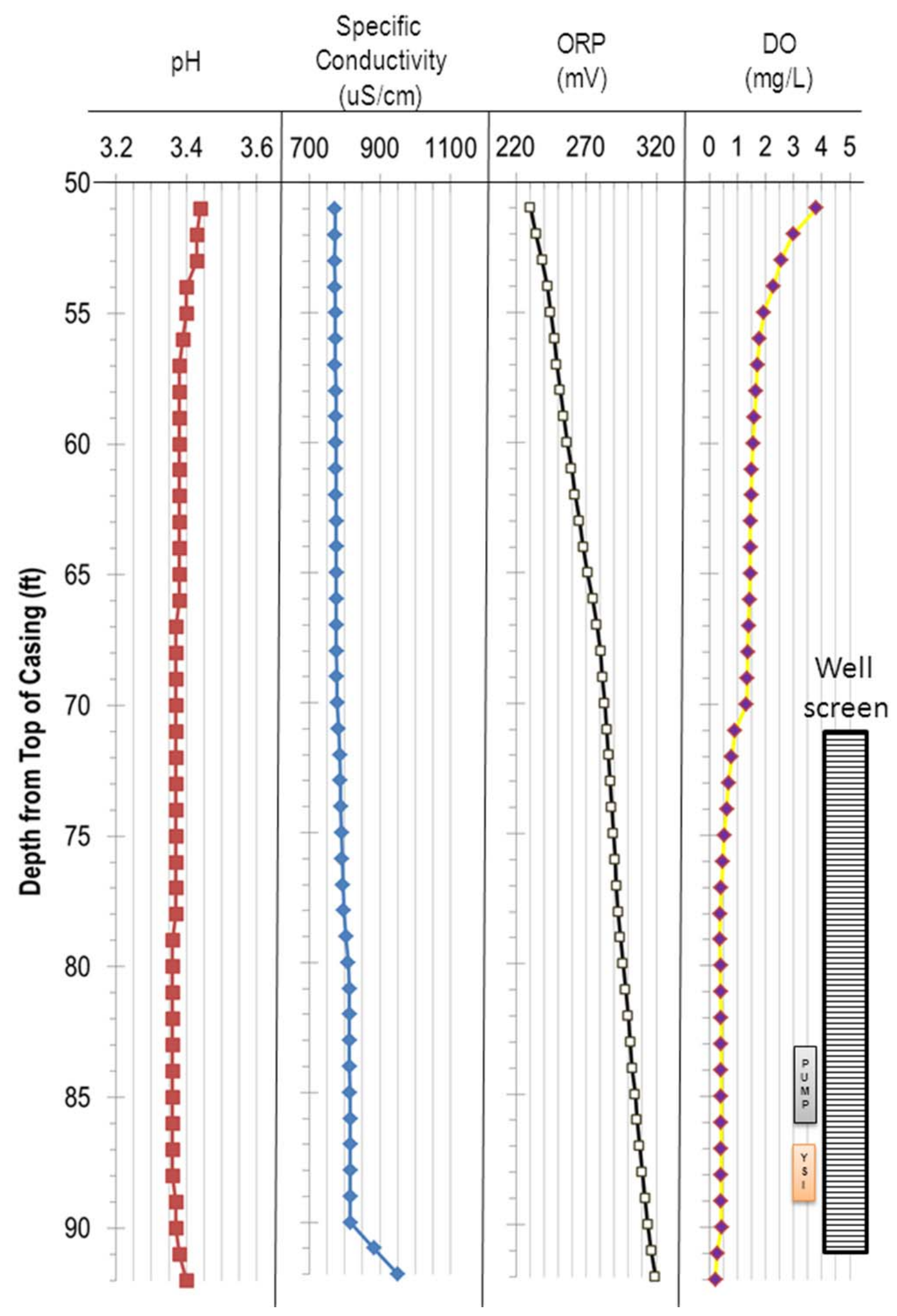

Figure 5. Field Parameter Depth Profile in FOB 16D 


\subsection{INJECTION}

The injectate solution consisted of 2,000 L (528 gal) of water, $20 \mathrm{~kg}$ of Huma $\mathrm{K}^{\odot}$ brand humate, and $0.2 \mathrm{~kg}$ of sodium bromide. The sodium bromide was added to act as a tracer during the test to evaluate the rate of movement of the injectate with the groundwater. These materials were mixed into two equal batches using a 330 gal, aluminum framed, plastic tote. Mixing was initially conducted with a paddle oar to wet all of the materials followed by the use of a drum pump to facilitate thorough mixing.

Figure 6 provides a layout schematic of the injection. A large volume peristaltic pump was used to transfer the injectate from the totes to the screen zone of the well. The injectate was not pressurized but rather allowed to flow under normal gravity condition. The tote tank was connected to the peristaltic pump via a valved outlet on the tote. A 100 micron filter was connected to the outlet side of the peristaltic pump to remove any large humate debris in an effort to prevent clogging of the well.

Once to the well, the injectate flowed through a 1-inch schedule 40 PVC casing with a $5 \mathrm{ft}$ screen attached at the bottom. This screen was set within the screen zone of the well at the desired elevation in order to accurately emplace (as much as possible) the material during injection. Monitoring of the water level in the well was conducted to evaluate the amount of head placed on the injectate. Mixing and injection took place over the course of seven hours on Monday, April 29, 2013. Appendix B provides pictures further documenting the setup and injection. 


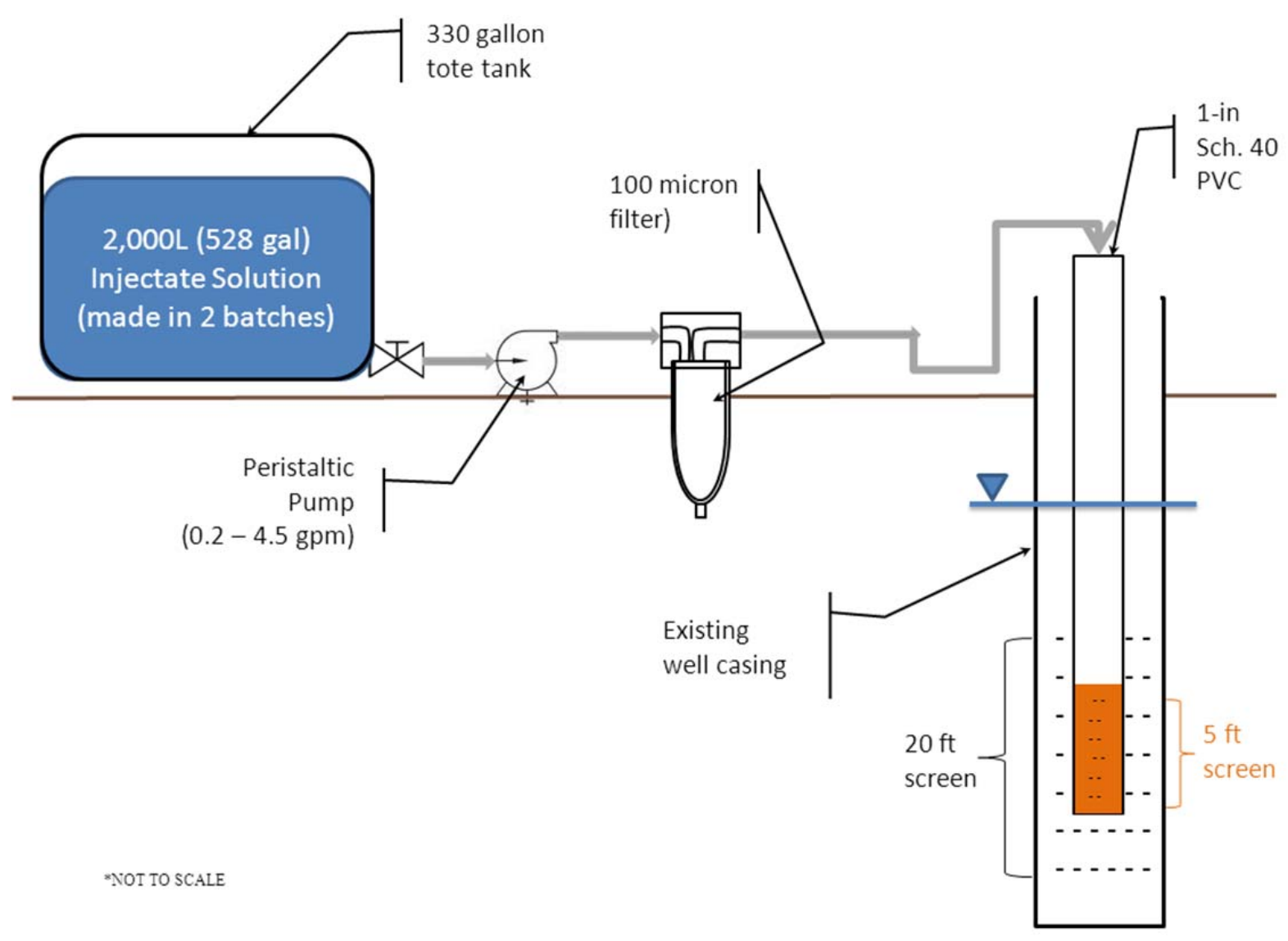

Figure 6. Schematic of Injection Setup

\subsection{SAMPLING AND ANALYSIS}

As shown on Table 1, wells FSB 94DR, 95DR, and 126D have mechanical pumps installed that are used for well sampling. Sampling of the injection well FOB 16D was performed using a QED bladder pump. During each sampling event, consistent pump rates were maintained to ensure consistency in sampling approach. In particular, pumping at FOB 16D consisted of micropurging, which is a low impact form of sampling that helps to reduce mixing and dilution effects while sampling.

Field parameters are monitored during purging at each well and once the parameters stabilize, purging is considered complete. 


\subsubsection{Laboratory Analyses}

Sampling and analysis was conducted according to SRS protocols and procedures (see Amidon et al. 2012 for further details). Prior to injection, the injection well (FOB 16D) along with the two background wells (FSB 94DR and 95DR) were sampled three times to establish baseline groundwater chemistry. The one downgradient well (FSB 126D) was sampled once prior to field deployment. After injection, the injection well (FOB 16D) was sampled 11 times while the two background wells (FSB 94DR and 95DR) were sampled 4 times. The one downgradient well (FSB 126D) was sampled once during the final sampling event.

Field filtering was conducted for all sample events. Additional unfiltered samples were also collected for radionuclides for two sample events (one baseline event and one post injection event). Samples were submitted to an offsite Environmental Protection Agency certified laboratory except iodide samples, which will be analyzed at the Savannah River National Laboratory (SRNL). Table 4 provides sample dates, well names, collection method, analyte codes and filter information for each of the samples events.

Table 4. Sample and Analysis Information for the Humate Injection Sample Events

\begin{tabular}{|c|c|c|c|c|c|c|}
\hline Event & $\begin{array}{l}\text { Sample } \\
\text { Date }\end{array}$ & Well & Sample Media & $\begin{array}{c}\text { Collection } \\
\text { Method }\end{array}$ & Analyte Code & $\begin{array}{c}\text { Filtered } \\
\text { (F) or } \\
\text { Unfiltered } \\
\text { (U) }\end{array}$ \\
\hline \multirow{4}{*}{$\begin{array}{c}\text { Baseline } \\
\text { Monitoring } \\
\text { \#1 }\end{array}$} & \multirow{4}{*}{$\begin{array}{c}\text { February } \\
27-28, \\
2013\end{array}$} & FOB 16D & Groundwater & $\begin{array}{l}\text { Bladder } \\
\text { Pump }\end{array}$ & $1,2,3,4,5,6 \mathrm{a}, \mathrm{b}$ & $\mathrm{U}, \mathrm{F}$ \\
\hline & & FSB 94DR & Groundwater & Pump & $1,2,3,4,5,6 \mathrm{a}, \mathrm{b}$ & $\mathrm{U}, \mathrm{F}$ \\
\hline & & FSB 95DR & Groundwater & Pump & $1,2,3,4,5,6$ a, b & $\mathrm{U}, \mathrm{F}$ \\
\hline & & FSB 126D & Groundwater & Pump & $1,2,3,4,5,6 \mathrm{a}, \mathrm{b}$ & $\mathrm{U}, \mathrm{F}$ \\
\hline \multirow{3}{*}{$\begin{array}{c}\text { Baseline } \\
\text { Monitoring } \\
\text { \#2 }\end{array}$} & \multirow{3}{*}{$\begin{array}{c}\text { March 27, } \\
2013\end{array}$} & FOB 16D & Groundwater & $\begin{array}{l}\text { Bladder } \\
\text { Pump }\end{array}$ & $1,2,3,4,5,6$ & $\mathrm{~F}$ \\
\hline & & FSB 94DR & Groundwater & Pump & $1,2,3,4,5,6$ & $\mathrm{~F}$ \\
\hline & & FSB 95DR & Groundwater & Pump & $1,2,3,4,5,6$ & $\mathrm{~F}$ \\
\hline \multirow{3}{*}{$\begin{array}{c}\text { Baseline } \\
\text { Monitoring } \\
\text { \#3 }\end{array}$} & \multirow{3}{*}{$\begin{array}{l}\text { April 24- } \\
25,2013\end{array}$} & FOB 16D & Groundwater & $\begin{array}{l}\text { Bladder } \\
\text { Pump }\end{array}$ & $1,2,3,4,5,6,7$ & $\mathrm{~F}$ \\
\hline & & FSB 94DR & Groundwater & Pump & $1,2,3,4,5,6,7$ & $\mathrm{~F}$ \\
\hline & & FSB 95DR & Groundwater & Pump & $1,2,3,4,5,6,7$ & $\mathrm{~F}$ \\
\hline
\end{tabular}




\begin{tabular}{|c|c|c|c|c|c|c|}
\hline Event & $\begin{array}{l}\text { Sample } \\
\text { Date }\end{array}$ & Well & Sample Media & $\begin{array}{c}\text { Collection } \\
\text { Method }\end{array}$ & Analyte Code & $\begin{array}{l}\text { Filtered } \\
\text { (F) or } \\
\text { Unfiltered } \\
\text { (U) }\end{array}$ \\
\hline \multirow{3}{*}{$\begin{array}{l}\text { Injection } \\
\text { Event }\end{array}$} & \multirow{3}{*}{$\begin{array}{l}\text { April 29, } \\
2013\end{array}$} & FRS-Tk1 & Injectate & Grab & 3 & $\mathrm{~F}$ \\
\hline & & FRS-Tk2 & Injectate & Grab & 3 & F \\
\hline & & FRS-Sol & $\begin{array}{l}\text { Humate in DI } \\
\text { water }\end{array}$ & Grab & $1,2,3$ & $\mathrm{~F}$ \\
\hline $\begin{array}{c}\text { Post } \\
\text { Injection \#1 }\end{array}$ & $\begin{array}{l}\text { April 30, } \\
2013\end{array}$ & FOB 16D & Groundwater & $\begin{array}{l}\text { Bladder } \\
\text { Pump }\end{array}$ & $1,2,3,4,5,6,7, \mathrm{c}, \mathrm{d}$ & $\mathrm{F}$ \\
\hline $\begin{array}{c}\text { Post } \\
\text { Injection \#2 }\end{array}$ & $\begin{array}{c}\text { May 1, } \\
2013\end{array}$ & FOB 16D & Groundwater & $\begin{array}{l}\text { Bladder } \\
\text { Pump }\end{array}$ & $1,2,3,4,5,6,7, \mathrm{c}, \mathrm{d}$ & $\mathrm{F}$ \\
\hline $\begin{array}{c}\text { Post } \\
\text { Injection \#3 }\end{array}$ & $\begin{array}{l}\text { May 2, } \\
2013\end{array}$ & FOB 16D & Groundwater & $\begin{array}{l}\text { Bladder } \\
\text { Pump }\end{array}$ & $1,2,3,4,5,6,7, \mathrm{c}, \mathrm{d}$ & $\mathrm{F}$ \\
\hline $\begin{array}{c}\text { Post } \\
\text { Injection \#4 }\end{array}$ & $\begin{array}{l}\text { May 6, } \\
2013\end{array}$ & FOB 16D & Groundwater & $\begin{array}{l}\text { Bladder } \\
\text { Pump }\end{array}$ & $1,2,3,4,5,6,7, \mathrm{c}, \mathrm{d}$ & $\mathrm{F}$ \\
\hline $\begin{array}{c}\text { Post } \\
\text { Injection \#5 }\end{array}$ & $\begin{array}{l}\text { May 13, } \\
2013\end{array}$ & FOB 16D & Groundwater & $\begin{array}{l}\text { Bladder } \\
\text { Pump }\end{array}$ & $1,2,3,4,5,6,7, \mathrm{c}, \mathrm{d}$ & $\mathrm{F}$ \\
\hline $\begin{array}{c}\text { Post } \\
\text { Injection \#6 }\end{array}$ & $\begin{array}{l}\text { May 15, } \\
2013\end{array}$ & FOB 16D & Groundwater & $\begin{array}{l}\text { Bladder } \\
\text { Pump }\end{array}$ & $1,2,3,4,5,6,7, \mathrm{c}, \mathrm{d}$ & $\mathrm{F}$ \\
\hline \multirow{3}{*}{$\begin{array}{c}\text { Post } \\
\text { Injection \#7 }\end{array}$} & \multirow{3}{*}{$\begin{array}{c}\text { May 21, } \\
2103\end{array}$} & FOB 16D & Groundwater & $\begin{array}{l}\text { Bladder } \\
\text { Pump }\end{array}$ & $1,2,3,4,5,6,7$ a, b, c & $\mathrm{U}, \mathrm{F}$ \\
\hline & & FSB 94DR & Groundwater & Pump & $1,2,3,4,5,6,7, a, b$ & $\mathrm{U}, \mathrm{F}$ \\
\hline & & FSB 95DR & Groundwater & Pump & $1,2,3,4,5,6,7, \mathrm{a}, \mathrm{b}$ & $\mathrm{U}, \mathrm{F}$ \\
\hline $\begin{array}{c}\text { Post } \\
\text { Injection \#8 }\end{array}$ & $\begin{array}{l}\text { June 4, } \\
2013\end{array}$ & FOB 16D & Groundwater & $\begin{array}{l}\text { Bladder } \\
\text { Pump }\end{array}$ & $1,2,3,4,5,6,7, \mathrm{c}$ & $\mathrm{F}$ \\
\hline \multirow{3}{*}{$\begin{array}{c}\text { Post } \\
\text { Injection \#9 }\end{array}$} & \multirow{3}{*}{$\begin{array}{c}\text { June 19, } \\
2013\end{array}$} & FOB 16D & Groundwater & $\begin{array}{l}\text { Bladder } \\
\text { Pump }\end{array}$ & $1,2,3,4,5,6,7, \mathrm{c}$ & $\mathrm{F}$ \\
\hline & & FSB 94DR & Groundwater & Pump & $1,2,3,4,5,6,7$ & $\mathrm{~F}$ \\
\hline & & FSB 95DR & Groundwater & Pump & $1,2,3,4,5,6,7$ & $\mathrm{~F}$ \\
\hline \multirow{3}{*}{$\begin{array}{l}\text { Post } \\
\text { Injection } \\
\# 10\end{array}$} & \multirow{3}{*}{$\begin{array}{c}\text { July 25, } \\
2013\end{array}$} & FOB 16D & Groundwater & $\begin{array}{l}\text { Bladder } \\
\text { Pump }\end{array}$ & $1,2,3,4,5,6,7, \mathrm{c}, \mathrm{e}$ & $\mathrm{F}$ \\
\hline & & FSB 94DR & Groundwater & Pump & $1,2,3,4,5,6,7$ & $\mathrm{~F}$ \\
\hline & & FSB 95DR & Groundwater & Pump & $1,2,3,4,5,6,7$ & $\mathrm{~F}$ \\
\hline \multirow{4}{*}{$\begin{array}{l}\text { Post } \\
\text { Injection } \\
\# 11\end{array}$} & \multirow{4}{*}{$\begin{array}{l}\text { August 28, } \\
2013\end{array}$} & FOB 16D & Groundwater & $\begin{array}{l}\text { Bladder } \\
\text { Pump }\end{array}$ & $1,2,3,4,5,6,7, \mathrm{c}, \mathrm{e}$ & $\mathrm{F}$ \\
\hline & & FSB 94DR & Groundwater & Pump & $1,2,3,4,5,6,7$ & $\mathrm{~F}$ \\
\hline & & FSB 95DR & Groundwater & Pump & $1,2,3,4,5,6,7$ & $\mathrm{~F}$ \\
\hline & & FSB 126D & Groundwater & Pump & $1,2,3,4,5,6,7$ & $\mathrm{~F}$ \\
\hline
\end{tabular}




\section{Notes for Table 4:}

Filtered:

1 - Metals (Al, Ba, Ca, Co, Fe, K, Mg, Mn, Na, Pb, S, Si, Sr, Zn)

2 - Anions (Cl, Br, NO2/NO3, SO4, PO4)

3 - TOC

4 - U-234, U-235, U-238

5 - Sr-90

6 - Tritium

7 - Total I, Organo-I, Iodate \& Iodide

Unfiltered:

a - U-234, U-235, U-238

b - Sr-90

Special Samples:

c - unpreserved radionuclide sample (U-234, U-235, U-238, Sr-90)

d - for acid preserved samples where separation was observed, analysis was performed on the water fraction, humate fraction and a homogenized fraction (U-234, U-235, U-238, Sr-90)

e - sample collected later during purge of FOB 16D (U-234, U-235, U-238)

As the humate injection study progressed, extra samples were collected and analyzed for FOB 16D in an effort to answer questions that arose during sampling. For example, during the first monitoring event after the humate injection, samplers and laboratory technicians observed that the humate fraction separated from the water in the bottles preserved with acid (Figure 7).

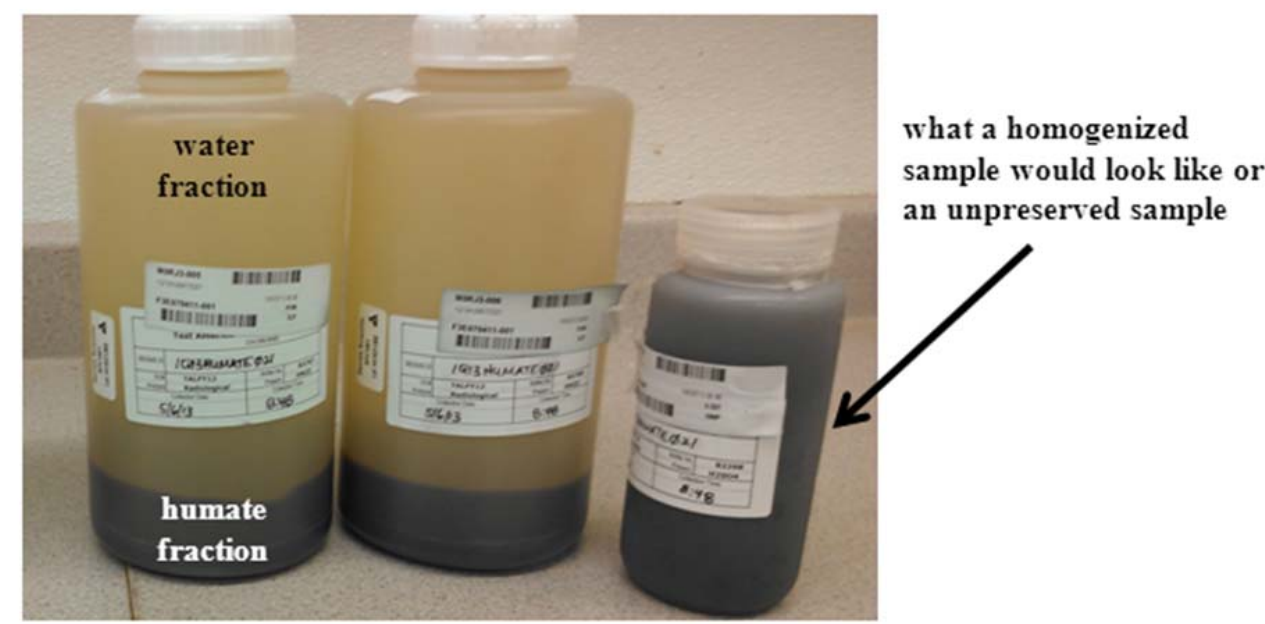

Figure 7. Picture of Acid Preserved Sample Bottles with Separation of Humate Fraction and Water Fraction 
For these samples, the laboratory performed additional analysis of uranium-234 (U-234), uranium-235 (U-235), uranium-238 (U-238) and Sr-90 to document concentrations in:

- the humate fraction of the bottle preserved with acid;

- $\quad$ the water fraction of the bottle preserved with acid;

- a homogenized sample of the bottle preserved with acid; and

- $\quad$ an unpreserved water sample (with all humate dissolved).

Additional sampling and analyses were also included for FOB 16D in the later monitoring events after samplers noted that longer purge times resulted in color variations in the samples. Presumably the samples that were darker contained more humate and the samples that were lighter contained less humate mixed with "fresh" upgradient water. Besides the color change, samplers also observed that the groundwater $\mathrm{pH}$ and specific conductivity began to rise after initial parameter stabilization. To determine whether purge volumes made a difference in sample results, additional samples were collected for long purge times and analyzed for U-234, U-235, U-238.

\subsubsection{Field Analyses}

For all of the monitoring wells, field parameters to include temperature, specific conductivity, $\mathrm{pH}$, oxidation-reduction potential (ORP), and DO were monitored ex-situ during each sample event using a YSI sonde with a multiparameter display system (MDS) and a flow-through cell. Turbidity was monitored on grab samples using a portable Hach turbidimeter. Stabilization of field parameters was used to determine when adequate well purging had taken place. Field parameters were also recorded in-situ in FOB 16D using a datalogging YSI sonde, which was powered by an ex-situ battery and solar panel system.

After the humate injection, grab samples were collected from FOB 16D to analyze color and approximate humate concentration using a Milton Roy Spectronic $20 \mathrm{D}+$ spectrometer at a wavelength of $430 \mathrm{~nm}$. Previous experience by SRNL demonstrated that visible light absorbance at this wavelength correlates strongly with the bulk humate concentration in solution. Figure 8 provides humate calibration data generated using Huma $\mathrm{K}^{\complement}$ brand humate. 
These analyses were performed in an effort to provide a reasonable approximation of the humate concentration during post injection monitoring and to supplement laboratory analyses of bromide, tritium and dissolved organic carbon (DOC).

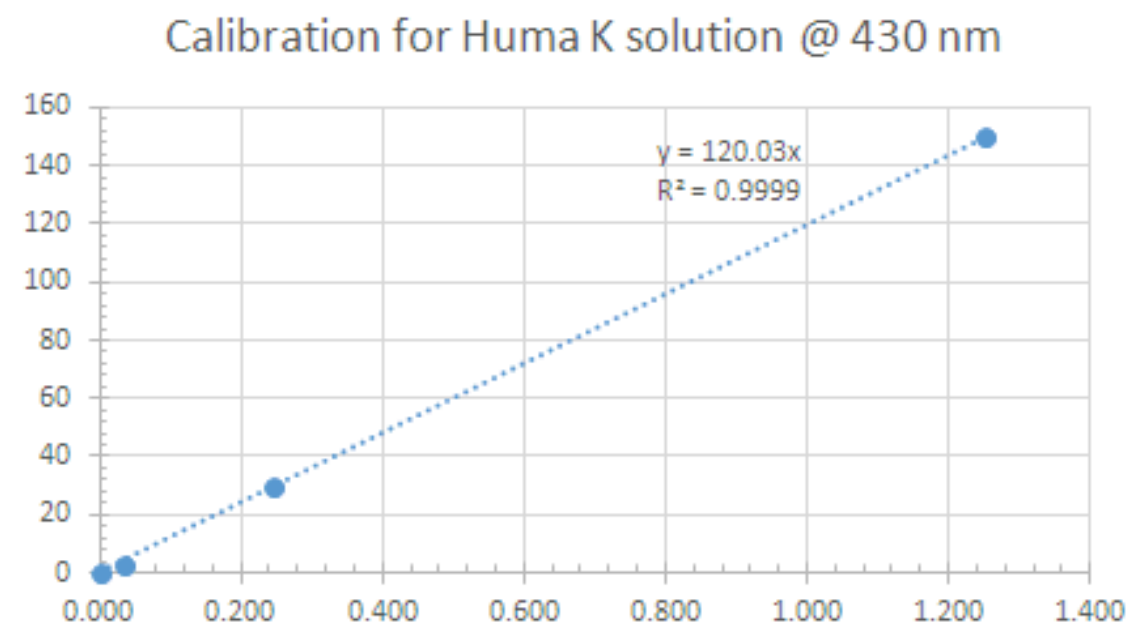

Figure 8. Spectrometer Calibration for Huma $\mathbf{K}^{\odot}$ Solution (mg/L)

\subsection{PRELIMINARY FIELD RESULTS}

Results from the field monitoring show that most of the excess humate (i.e., humate that did not sorb to the sediments) has flushed through the surrounding formation. Furthermore, the data indicate that the test was successful in loading a band of sediment surrounding the injection point to a point where $\mathrm{pH}$ could return to near normal during the study timeframe. Figure 9 provides approximate humate concentrations in FOB 16D field samples. As expected, the injectate solution contained approximately 10,000 mg/L of Huma $\mathrm{K}^{\odot}$ brand humate. Humate concentrations in the samples varied between $3000 \mathrm{mg} / \mathrm{L}$ and $5000 \mathrm{mg} / \mathrm{L}$ immediately after injection and then gradually decreased to less than $10 \mathrm{mg} / \mathrm{L}$ by the final sampling event conducted August 28, 2013. 


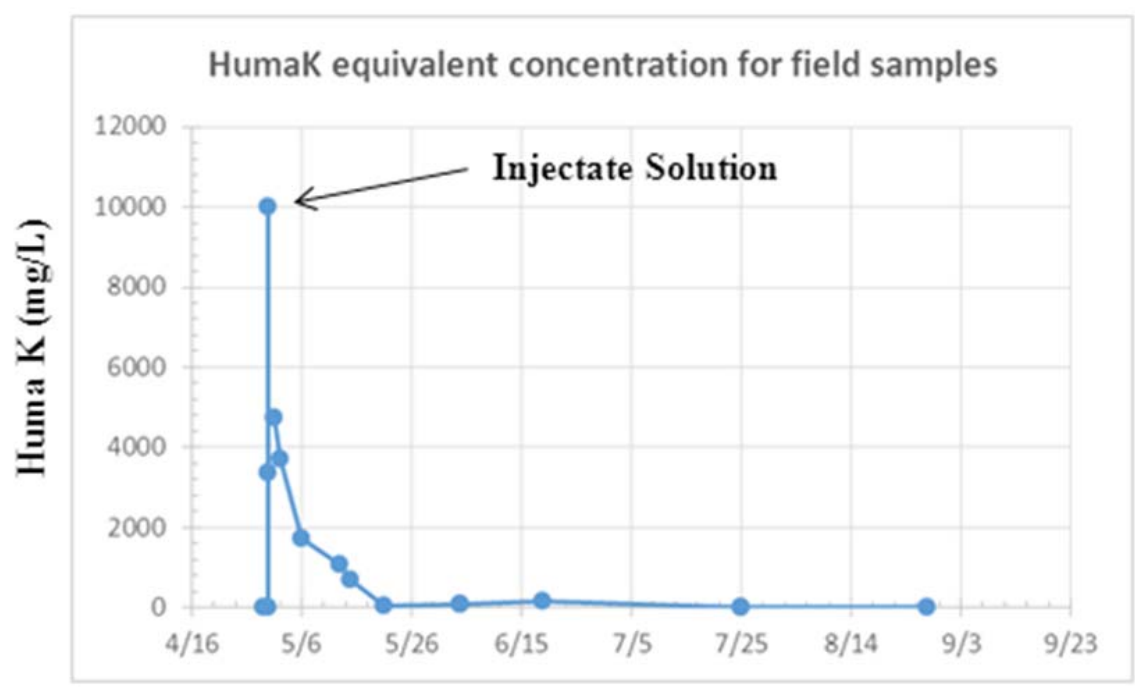

Sample Event

Figure 9. Huma $\mathrm{K}^{\odot}$ Concentrations in the Injectate Solution and FOB 16D

Figure 10 shows $\mathrm{pH}$ measurements from the YSI flow-through cell and represent $\mathrm{pH}$ values of the collected field samples. Like the humate concentrations, there is a sharp spike initially after injection. $\mathrm{pH}$ values dropped greatly during the first month and then gradually returned to below 4. As of the last sampling event, $\mathrm{pH}$ remained slightly elevated ( 3.6) compared to baseline measurements ( 3.3).

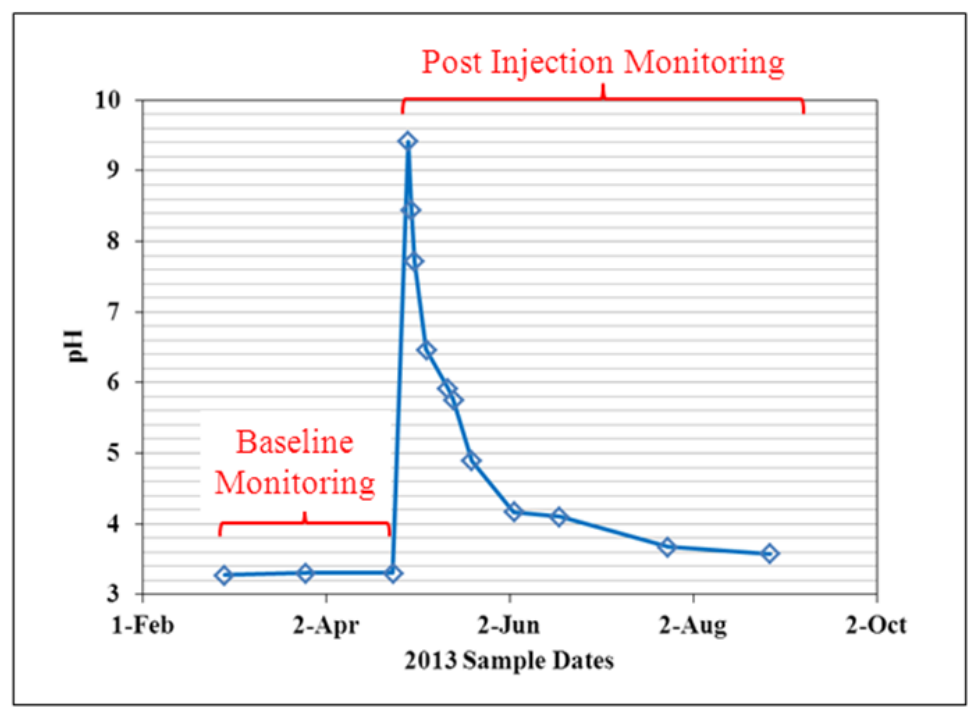

Figure 10. pH in FOB 16D: Baseline Monitoring versus Post-Injection Monitoring 
Figure 11 provides results from the continuous field parameter monitoring with the in-situ YSI sonde. Injection of the two batches of humate is evident by the spikes in temperature, specific conductivity, $\mathrm{pH}$ and DO along with the decrease in ORP. During the post monitoring, temperature and DO quickly returned to near normal conditions. With time, specific conductivity, $\mathrm{pH}$ and ORP returned to near normal conditions. Small "blips" are

sometimes evident during the post monitoring with specific conductivity, $\mathrm{pH}$ and ORP and reflect the individual sample events. The in-situ YSI sonde was situated immediately below the intake for the bladder pump (refer to Figure 5).

\subsection{FUTURE WORK}

Laboratory analyses and data reports are not yet complete. After all of the laboratory data results are received, data will be scrutinized to look at trends and correlations. Bromide, tritium and approximate humate concentrations will be used to look at mixing and dilution effects. If the data reveal binding of uranium and/or other constituents, additional sampling may be needed to investigate the longevity of the humate as a treatment. 


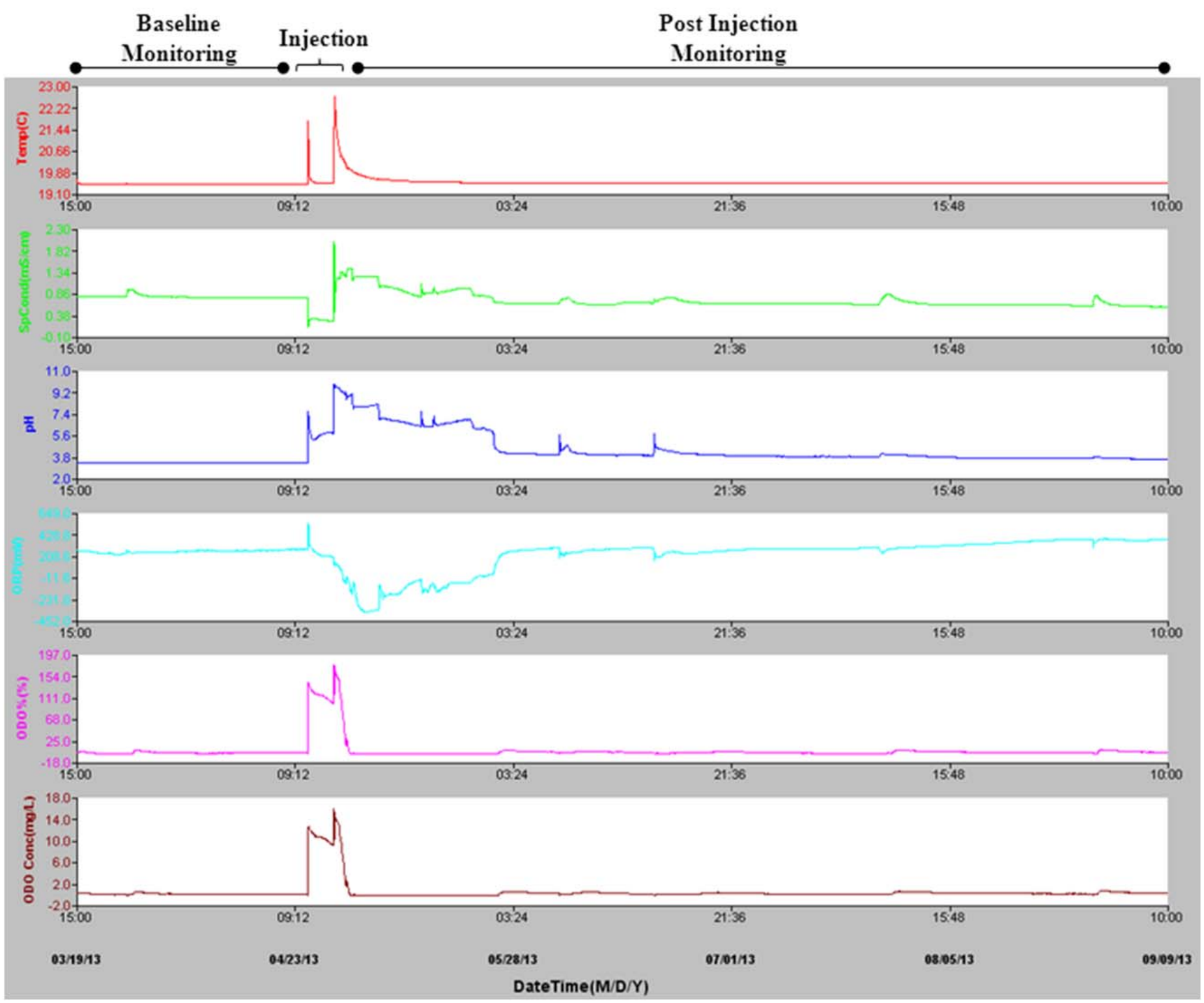

Figure 11. Continuous Monitoring YSI Data from FOB 16D 


\subsection{REFERENCES}

Amidon, M. B., Denham, M. E. and Millings, M. R., 2012. Sampling and Analysis Plan for Humate Push-Monitor Technology Demonstration at the F-Area Seepage Basins, Savannah River Site (U), SRNL-RP-2013-00040, Savannah River Nuclear Solutions, Aiken, SC, December 2012.

Amidon, M. B. and Millings, M. R., 2013. Fourmile Branch Seepline Assessment at the Fand H-Area Seepage Basins, Savannah River Site (U), SRNL-RP-2013-00362, Savannah River Nuclear Solutions, Aiken, SC, May 2013.

Cummins, C. L., Hetrick, C. S. and Martin, D. K., 1991. Radioactive Releases at the Savannah River Site, 1954-1989, WSRC-RP-91-684, Westinghouse Savannah River Company, Aiken, SC, February 1991.

Dixon, K. L. and Rogers, V. A. 1994. Semi-Annual Sampling of Fourmile Branch and Its Seeplines in the F and H Areas of SRS (U), WSRC-TR-93-293, Westinghouse Savannah River Company, Aiken, SC, April 1994.

Dixon, K. L., 1996. Monitoring of Water Levels in the Wetlands of Fourmile Branch near Fand H-Areas of SRS, WSRC-TR-96-0289, Westinghouse Savannah River Company, Aiken, SC, 1996.

Dixon, K. L., Rogers, V. A., Conner, S. P., Cummings, C. L., Gladden, J. B., and Weber, J. M., 1997. Geochemical and Physical Properties of Wetland Soils at the Savannah River Site, WSRC-TR-96-0115, Westinghouse Savannah River Company, Aiken, SC, May 1997.

Fenimore, J. W. and Horton, J. H., 1972. Operating History and Environmental Effects of Seepage Basins in chemical Separations Areas of the Savannah River Plant, DPST-72-548, E. I. du Pont de Nemours \& Co, Savannah River Laboratory, Aiken, SC, 1972.

Friday, G. P., 2001. Chemical Properties of Pore Water and Sediment at Three Wetland Sites Near the F- and H-Area Seepage Basins, Savannah River Site, WSRC-TR-2001-00241, Westinghouse Savannah River Company, Aiken, SC, May 2001.

Friday, G. P., 1997. Environmental Summary of the F- and H-Area Seepage Basins Groundwater Remediation Project, Savannah River Site, WSRC-TR-97-0130, Westinghouse Savannah River Company, Aiken, SC, 1997.

Friday, G. P., Dunn, D. L., and Halverson, N.V., 2001. Summary of Environmental Investigations in the Vicinity of the F- and H-Area Seepage Basins, Savannah River Site, WSRC-TR-2001-00548, Westinghouse Savannah River Company, Aiken, SC, December 2001. 
Haselow, J. S., Harris, M., Looney, B. B., Halverson, N. V. and Gladden, J. B., 1990. Analysis of Soil and Water at the Four Mile Creek Seepline near the F\&H Areas of SRS (U), WSRC-RP-90-0591, Westinghouse Savannah River Company, Aiken, SC, June 1990.

Horton, J. H. and Carothers, G. A., 1974. Nitrate in the Separations Area Seepage Basins, DPST-74-293, E. I. du Pont de Nemours \& Co, Savannah River Laboratory, Aiken, SC, March 1974.

Kantelo, M. V., 1987. Summary of I-129 Measurements in Ground and Surface Waters, DPST-87-820, E. I. du Pont de Nemours \& Co, Savannah River Laboratory, Aiken, SC, November 1987.

Killian, T. H., Kolb, N. L., Corbo, P., and Marine, I. W., 1987a. Environmental Information Document F-Area Seepage Basins, DPST-85-704, E. I. du Pont de Nemours \& Co, Savannah River Laboratory, Aiken, SC, March 1987.

Koch, J. W. and Dixon, K. L., 1998. Comprehensive Sampling of Fourmile Branch and Its Seeplines in the F and H Areas of SRS: June 1996, and March 1997 (U), WSRC-TR-9800287, Westinghouse Savannah River Company, Aiken, SC, August 1998.

Looney, B. B., Cantrell, J. E., and Cook, J. R., 1988. Sampling and Analysis of Surface Water in the Vicinity of the F- and H-Area Seepage Basins, DPST-88-229, E. I. du Pont de Nemours \& Co, Savannah River Laboratory, Aiken, SC, January 1988.

Millings, M. R., Looney, B. B., Halverson, N. V. and Nichols, R. L., 2008. Detoxification of Copper in Surface Water Discharges Using Soluble Humic Acid Amendment: Technical Summary of Results, WSRC-STI-2008-000105, Washington Savannah River Company, Aiken, SC, February 2008.

Millings, M. R. and Amidon, M. B., 2013. Fourmile Branch Tree Kill Assessment at the Fand H-Area Hazardous Waste Management Facilities, SRNL-TR-2013-00074, Savannah River Nuclear Solutions, Aiken, SC, May 2013.

Millings, M. R., Caldwell, E. F., and Looney, B. B., 2013. H12 Outfall Assessment: Monitoring the Effectiveness of Humate for Copper Detoxification, SRNL-TR-2013-00162, Savannah River Nuclear Solutions, Aiken, SC, September 2013.

Reichert, S. O. and Fenimore, J. W., 1962. Lithology and Hydrology of Radioactive Waste Disposal Sites at the Savannah River Plant, DPSPU-62-30-21B, E. I. du Pont de Nemours \& Co, Savannah River Plant, Aiken, SC, October 1962.

SRNS, 2012. Annual Corrective Action Report for the F-Area Hazardous Waste Management Facility, the H-Area Hazardous Waste Management Facility, and the Mixed Waste Management Facility (U), SRNS-RP-2012-00045, Savannah River Nuclear Solutions, LLC, Aiken, SC, April 2012. 
SRNS, 2013. Underground Injection Control Permit Application for Humate Injection at the F Area Hazardous Waste Management Facility (U), SRNL-RP-2013-00039, Savannah River Nuclear Solutions, LLC, Aiken, SC, February 2012.

Wan, J., Dong, W. and Tokunaga, T. K., 2011. "Method to Attenuate U(VI) Mobility in Acidic Waste Plumes Using Humic Acids”, Environ. Sci. Technology, v. 45, p.2331-2337.

WSRC, 2000a. Monitoring Plan for the Wetlands Downgradient from the F-and H-Area Seepage Basins, Savannah River Site, WSRC-TR-99-00146, Revision 1, Westinghouse Savannah River Company, Aiken, SC, 2000.

WSRC, 2000b. F-Area Hazardous Waste Management Facility Corrective Action Report (U): First and Second Quarter 2000, WSRC-TR-2000-00243, Westinghouse Savannah River Company, Aiken, SC, 2000.

WSRC, 2005. Annual Corrective Action Report for the F-Area Hazardous Waste Management (HWMF), the H-Area HWMF, and the Mixed Waste Management Facility, WSRC-RP-2005-4011, Westinghouse Savannah River Company, Aiken, SC, 2005. 


\section{APPENDIX A. MEDIAN METAL CONCENTRATIONS IN HUMA K ${ }^{\odot}$}

(Data from Millings et al., 2008 study with Huma K)

\begin{tabular}{|c|c|c|c|c|c|c|c|}
\hline & & & sample 1 & sample 2 & sample 3 & sample 4 & Median \\
\hline Analyte & PQL & Units & 1-HK & 2-HK & 3-HK & 4-HK & \\
\hline Ag & 0.005 & $\mathrm{mg} / \mathrm{L}$ & $<0.005$ & $<0.005$ & $<0.005$ & $<0.005$ & $<0.005$ \\
\hline Al & 0.05 & $\mathrm{mg} / \mathrm{L}$ & 7.85 & 8.004 & 7.77 & 7.843 & 7.85 \\
\hline As & 0.005 & $\mathrm{mg} / \mathrm{L}$ & 0.0259 & 0.0242 & 0.0254 & 0.0231 & 0.025 \\
\hline B & 0.05 & $\mathrm{mg} / \mathrm{L}$ & $<0.05$ & $<0.05$ & $<0.05$ & $<0.05$ & $<0.05$ \\
\hline Ba & 0.05 & $\mathrm{mg} / \mathrm{L}$ & $<0.05$ & 0.035 & $<0.05$ & $<0.05$ & $<0.05$ \\
\hline Be & 0.001 & $\mathrm{mg} / \mathrm{L}$ & 0.005 & 0.0051 & 0.005 & 0.005 & 0.005 \\
\hline Ca & 0.05 & $\mathrm{mg} / \mathrm{L}$ & 7.052 & 7.238 & 7.137 & 7.148 & 7.14 \\
\hline Cd & 0.001 & $\mathrm{mg} / \mathrm{L}$ & $<0.001$ & $<0.001$ & $<0.001$ & $<0.001$ & $<0.001$ \\
\hline Co & 0.02 & $\mathrm{mg} / \mathrm{L}$ & $<0.02$ & $<0.02$ & $<0.02$ & $<0.02$ & $<0.02$ \\
\hline $\mathrm{Cr}$ & 0.005 & $\mathrm{mg} / \mathrm{L}$ & 0.0236 & 0.0232 & 0.0219 & 0.0239 & 0.023 \\
\hline $\mathbf{C u}$ & 0.01 & $\mathrm{mg} / \mathrm{L}$ & 0.0373 & 0.0379 & 0.0368 & 0.0376 & 0.037 \\
\hline $\mathbf{F e}$ & 0.02 & $\mathrm{mg} / \mathrm{L}$ & 7.756 & 7.738 & 7.431 & 7.784 & 7.75 \\
\hline Hg & 0.00002 & $\mathrm{mg} / \mathrm{L}$ & 0.000344 & 0.000336 & 0.000346 & 0.000325 & 0.00034 \\
\hline $\mathbf{K}$ & $\mathrm{n} / \mathrm{a}$ & $\mathrm{mg} / \mathrm{L}$ & & & see notes* & & \\
\hline Mg & 0.05 & $\mathrm{mg} / \mathrm{L}$ & 0.7657 & 0.7781 & 0.7623 & 0.7615 & 0.764 \\
\hline Mn & 0.01 & $\mathrm{mg} / \mathrm{L}$ & 0.0157 & 0.0163 & 0.0156 & 0.0158 & 0.016 \\
\hline Mo & 0.02 & $\mathrm{mg} / \mathrm{L}$ & $<0.02$ & $<0.02$ & $<0.02$ & $<0.02$ & $<0.02$ \\
\hline $\mathrm{Na}$ & 0.03 & $\mathrm{mg} / \mathrm{L}$ & 1.232 & 1.274 & 1.237 & 1.274 & 1.26 \\
\hline $\mathrm{Ni}$ & 0.01 & $\mathrm{mg} / \mathrm{L}$ & 0.0356 & 0.036 & 0.0352 & 0.0349 & 0.035 \\
\hline $\mathbf{P b}$ & 0.002 & $\mathrm{mg} / \mathrm{L}$ & 0.0048 & 0.0044 & 0.0036 & 0.0033 & 0.004 \\
\hline Sb & 0.005 & $\mathrm{mg} / \mathrm{L}$ & $<0.005$ & $<0.005$ & $<0.005$ & $<0.005$ & $<0.005$ \\
\hline Se & 0.005 & $\mathrm{mg} / \mathrm{L}$ & $<0.005$ & $<0.005$ & 0.0057 & $<0.005$ & $<0.005$ \\
\hline Sn & 0.01 & $\mathrm{mg} / \mathrm{L}$ & $<0.01$ & $<0.01$ & $<0.01$ & $<0.01$ & $<0.01$ \\
\hline $\mathbf{T i}$ & 0.05 & $\mathrm{mg} / \mathrm{L}$ & 0.2571 & 0.2601 & 0.2558 & 0.2576 & 0.257 \\
\hline $\mathbf{V}$ & 0.01 & $\mathrm{mg} / \mathrm{L}$ & 0.0593 & 0.0606 & 0.0589 & 0.0598 & 0.060 \\
\hline Zn & 0.01 & $\mathrm{mg} / \mathrm{L}$ & 0.0172 & 0.0175 & 0.0171 & 0.0173 & 0.017 \\
\hline
\end{tabular}

Tabulated values are the results for the analysis of a Huma K concentrate containing $1250 \mathrm{mg} / \mathrm{L}$ amendment or $500 \mathrm{mg}$ DOC / L (assuming Huma $\mathrm{K}$ is $40 \%$ carbon)

*Potassium (K) signal was saturated and not reported by lab 


\section{APPENDIX B. PICTURES OF HUMATE INJECTION}

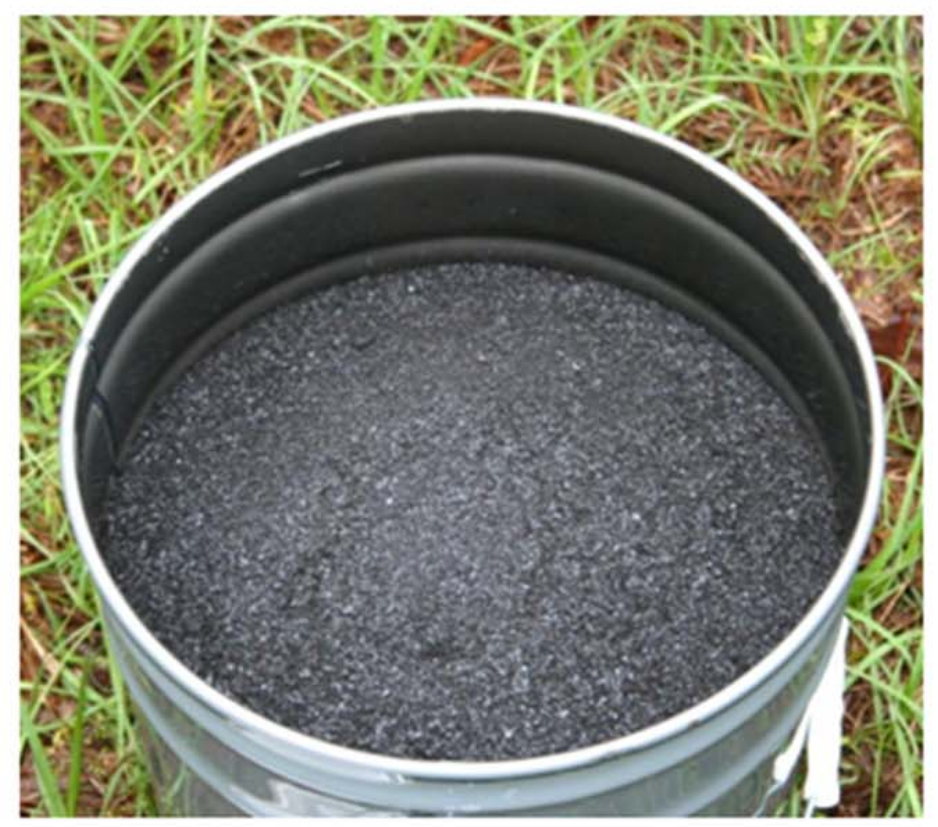

B1. Huma K (dry, flaked, potassium humate)

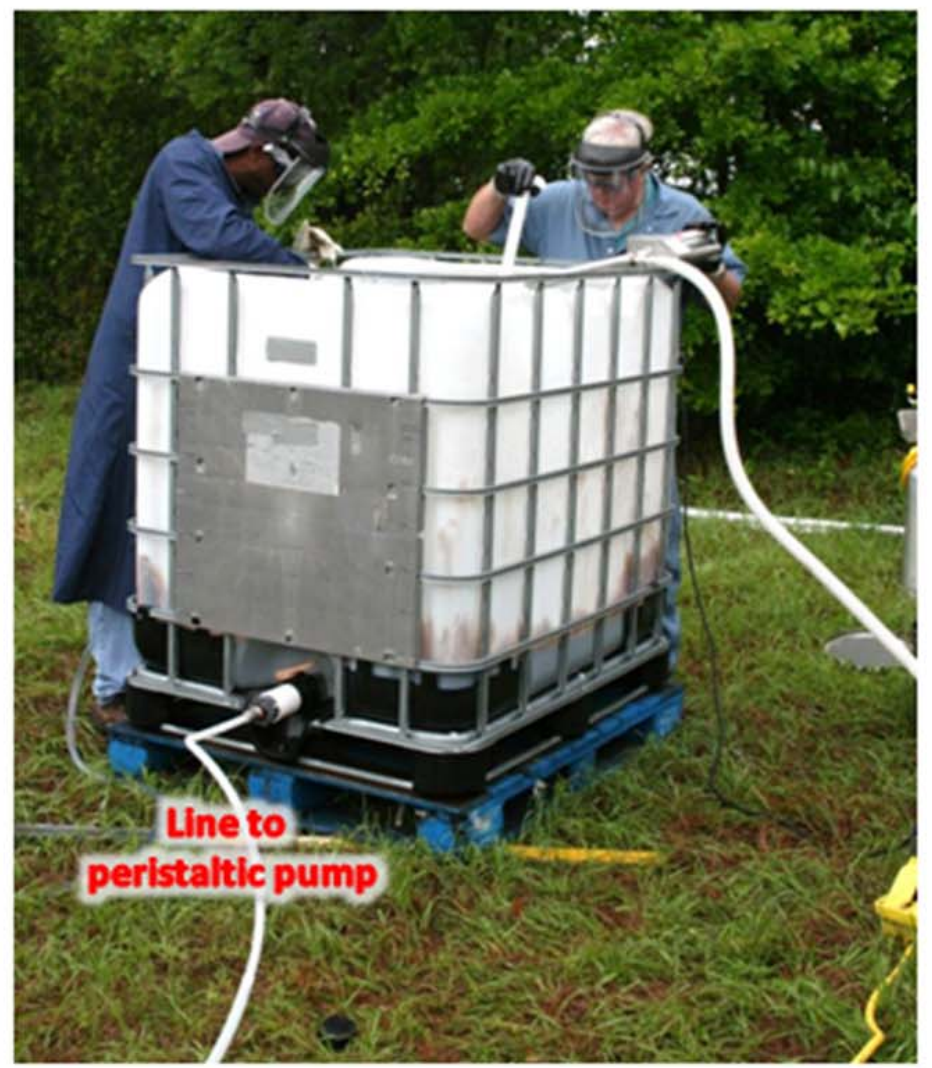

B2. 330-Gallon, Aluminum Framed Plastic Tote 


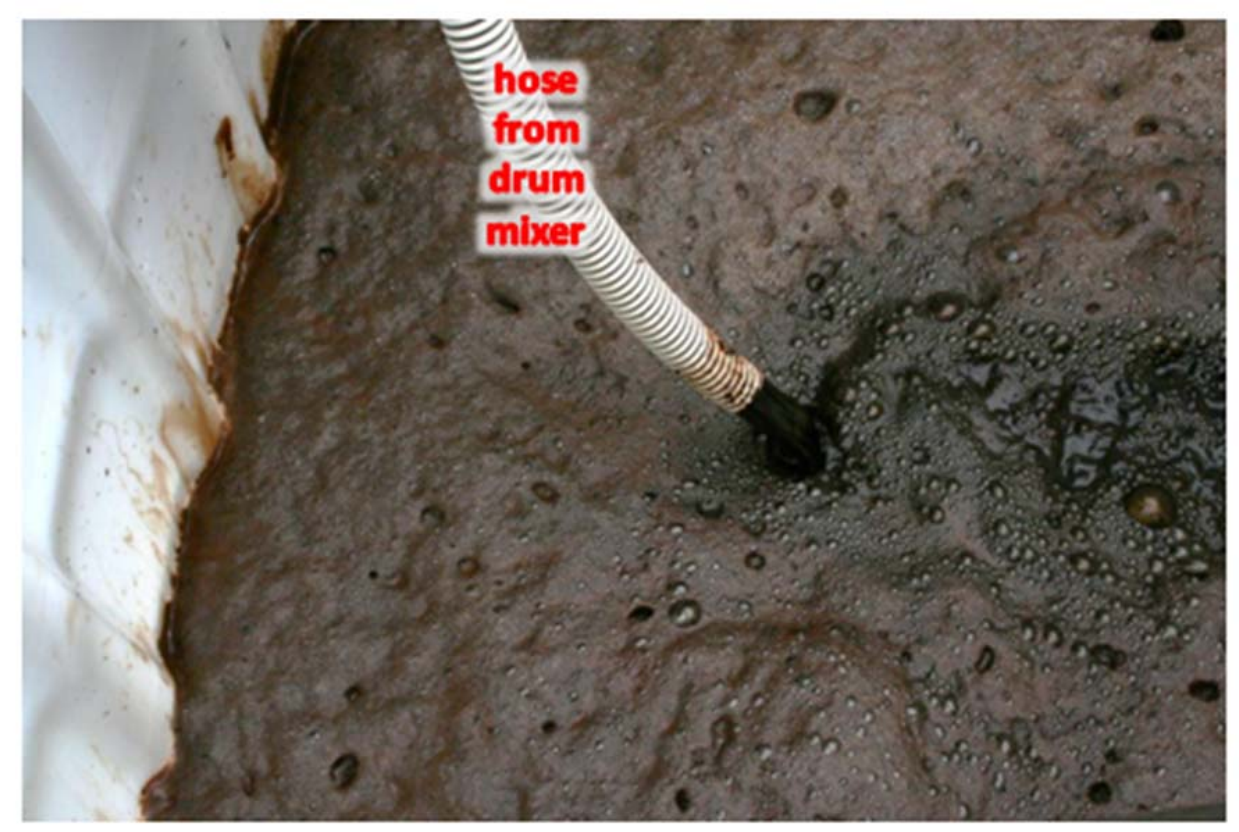

B3. Injectate Solution Mixing in the Tote

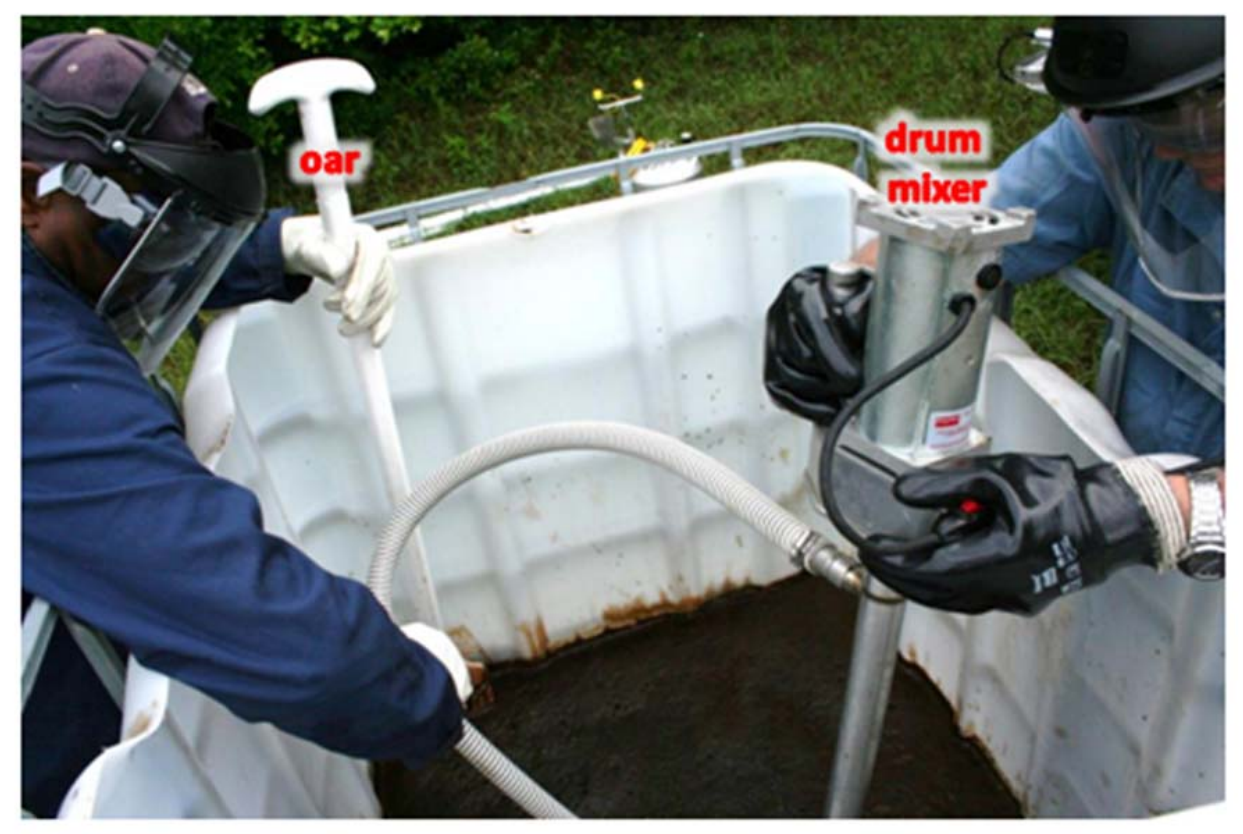

B4. Mixing of Injectate Solution 


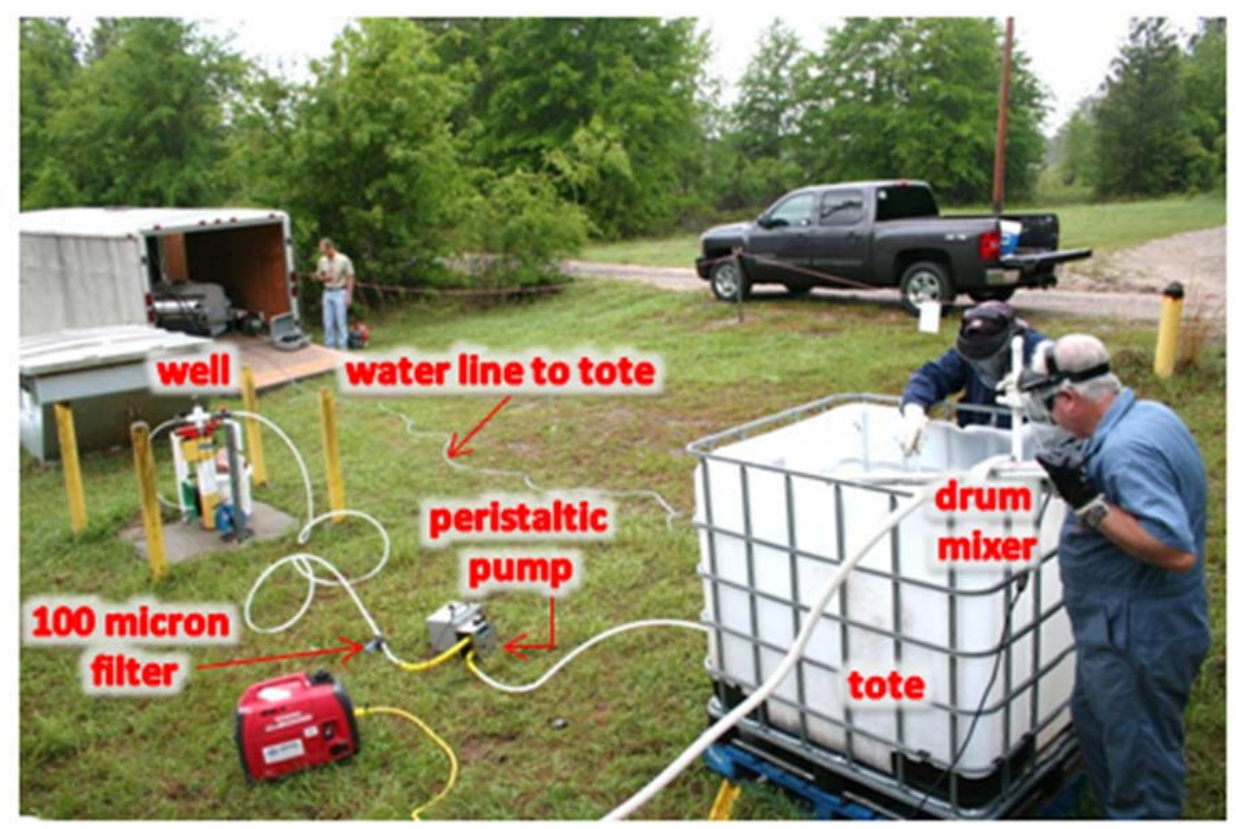

B5. Setup for Injecting Humate Solution

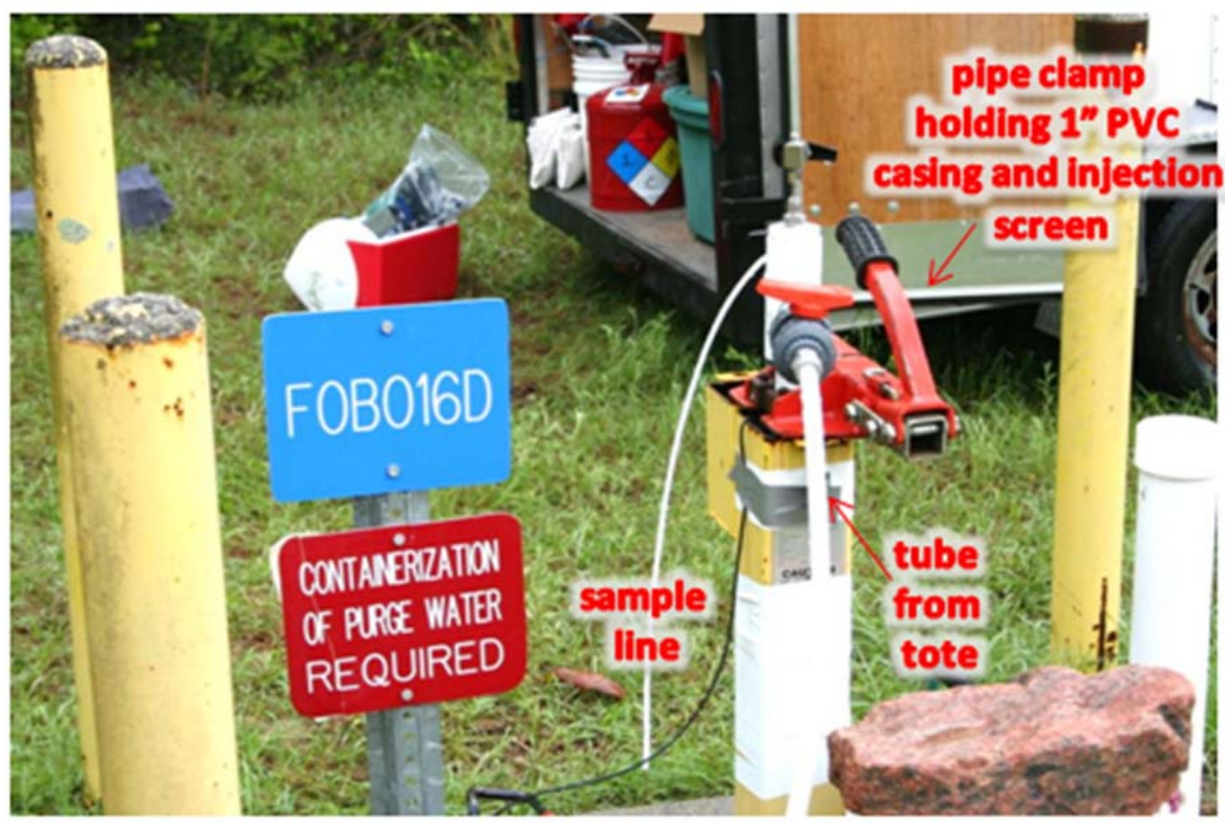

B6. Injection Well 


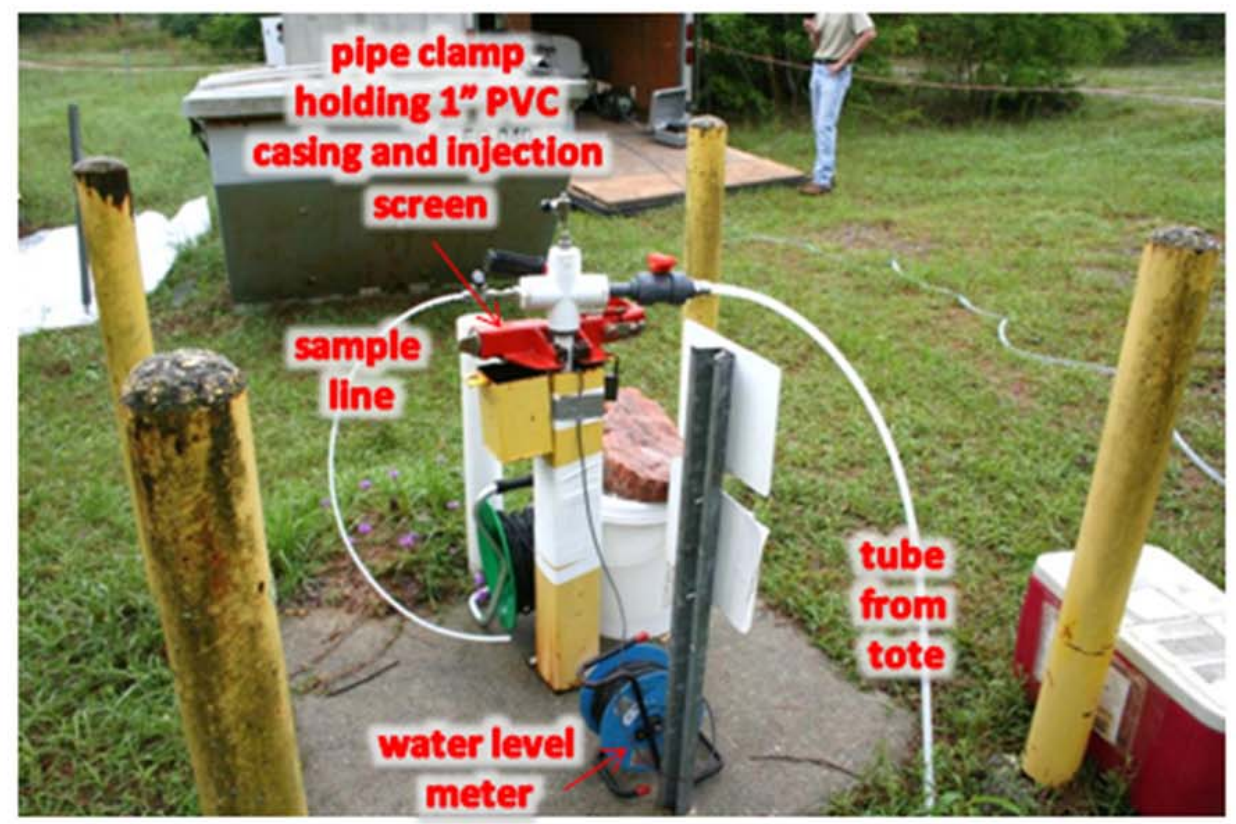

B7. Injection Manifold, Sample Port, Water Level Meter

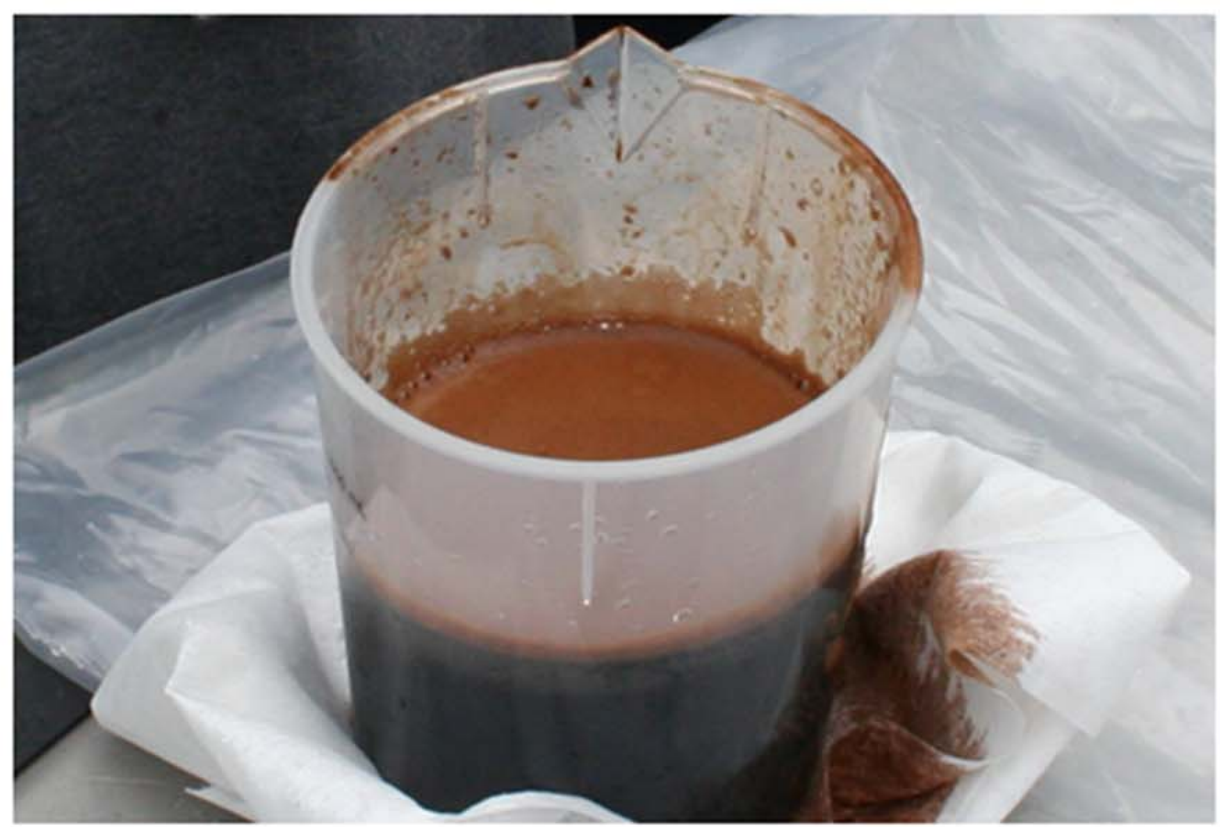

B8. Injectate Solution 